\title{
mutoscópio de Santos Dumont e a poética do found footagel
}

Santos Dumont's mutoscope and the poetics of found footage

\section{CARLOS ADRIANO2}

Universidade de São Paulo / São Paulo, SP, Brasil

RESUMO: $\bigcirc$ artigo tem como base o estudo de um raro e extraordinário artefato cinematográfico de Santos Dumont, pertencente à coleção do Museu Paulista da Universidade de São Paulo: um carretel de mutoscópio produzido em 1901. A partir de um inventário analítico sobre a descoberta, a identificação e a restauração do objeto, são abordados o gênero e os procedimentos da reapropriação cinematográfica de arquivo (found footage), apresentando um esboço de taxonomia com suas variantes básicas e mencionando o filme experimental de found footage Santoscópio = Dumontagem, realizado em 2010 como consequência da restauração do filme-mutoscópio de 1901. São apontadas algumas questões corolárias a partir de conceitos apropriados e trazidos ao contexto, como o da meta-história de Hollis Frampton, o da alegoria das ruínas de Walter Benjamin e o da imagem sobrevivente de Aby Warburg. $\bigcirc$ artigo pretende ainda propor a reapropriação de arquivo como método e poética.

PALAVRAS-CHAVE: Arquivo. Cinema. Found Footage. Museu Paulista da USP. Reapropriação. Santos Dumont.

ABSTRACT: This article is based on the study of a rare and extraordinary cinematographic artefact of Santos Dumont, which belongs to the collection of the Museu Paulista of the University of São Paulo: a mutoscope reel produced in 1901. From an analytical inventory about the discovery, as well as the identification and the restoration of the object, the genre and the procedures of reappropriating the film archive (found footage) are presented, introducing a sketch of taxonomy with its basic variants and mentioning the experimental found footage film Santoscope $=$ Dumontage, produced in 2010 from the restoration of the 1901 mutoscope film.

\begin{abstract}
1. Este artigo é baseado em minha tese de doutorado (ROSA, 2008), desenvolvida na Escola de Comunicações e Artes da Universidade de São Paulo (ECA-USP) com bolsa da Fundação de Amparo à Pesquisa do Estado de São Paulo (Fapesp) e orientada pelo Prof. Dr. Ismail Xavier, a quem agradeço pela privilegiada e inestimável interlocução.

2. Doutor em Estudo dos Meios e da Produção Mediática pela USP (bolsa Fapesp); pós-doutor em Comunicação e Semiótica pela Pontifícia Universidade Católica de São Paulo (PUC-SP), com bolsa Fapesp; e pós-doutor em Meios e Processos Audiovisuais pela USP, com bolsa do Programa Nacional de Pós-Doutorado da Coordenação de Aperfeiçoamento de Pessoal de Nível Superior (PNPD/Capes). Cineasta e realizador de filmes-poemas de reapropriação de arquivo (found footage). E-mail: <adriano.carlos.ca@ gmail.com>.
\end{abstract}


3. Dedico este artigo a Bernardo Vorobow (in memorian), programador de filmes e arquivos que era apaixonado por cinema e aviação e que, em nossas venturas de 27 anos, de perto acompanhou este voo ao redor de Santos Dumont.
Some corollary questions are made, using appropriate concepts which are brought into context, such as Hollis Frampton's metahistory, Walter Benjamin's allegory of the ruins, and Aby Warburg's survival of the images. This article also intends to propose the reappropriation of archives as a method and as poetics.

KEYWORDS: Archive. Cinema. Found Footage. Paulista Museum. Reappropriation. Santos Dumont.

\section{INTRODUÇÃO}

Em 2002 encontrei $^{3}$ no acervo do Museu Paulista da Universidade de São Paulo um carretel com 1.339 cartões fotográficos - 658 cartões com imagem e 681 cartões brancos ou pretos -, sem identificação de título, autoria, data, local ou processo de produção. Se animados por mecanismo apropriado e reproduzidos em movimento sequencial, os cartões com imagem exibem Santos Dumont apresentando para a câmera e para um interlocutor o que aparenta ser o projeto de um invento.

Não existia qualquer informação mais precisa sobre a peça preciosa e desconhecida (esquecida até), além de seu número de tombo na Coleção Santos Dumont do Museu Paulista. O objeto estava catalogado como "cinedoscópio" no banco de dados. A única referência informativa que foi possível achar no acervo do Museu, além de uma episódica menção entre um recorte perdido do Jornal de Notícias, foi o registro no inventário de doação (1935) da família de Santos Dumont, que classifica a peça como "roda cinematográfica". Ambas as denominações eram errôneas.

$\bigcirc$ carretel pertence a um dispositivo que existiu simultaneamente à consagração do cinema, tal como projetado pelo cinematógrafo Lumière (1895). Após extensa (e detetivesca) pesquisa, confirmou-se que se tratava de um mutoscópio, aparelho que exibia em loop, para um espectador individual, uma série de pequenas fotografias reproduzidas de um filme $68 \mathrm{~mm}$ e carregadas num carretel de metal. No formato original de filme, o material também era exibido sobre tela, para uma plateia, por meio de um projetor aparelhado para o magnífico formato $68 \mathrm{~mm}$.

Procedeu-se à restauração da peça. $\bigcirc$ carretel (que estava partido) foi desmontado, os cartões foram escaneados, e os arquivos tiff das imagens foram editados em programa digital de edição de vídeo, sendo reordenados em 
sequência e acertada sua posição no quadro, de modo a produzir um movimento contínuo: as fotografias do carretel foram convertidas em fotogramas, reconstituindose assim sua natureza cinematográfica. $\bigcirc$ filme restaurado, objeto singular dos primórdios do cinema, sem equivalência na história brasileira, é um raro registro em movimento de Santos Dumont, sem correspondência da figura mediática do inventor brasileiro no horizonte perdido de uma cultura visual do século XX.

Santos Dumont (1873-1932) foi um cultor fervoroso da modernidade e teve cravada no próprio corpo uma de suas marcas distintivas: a velocidade e seu rastro - fascínio pela máquina, ânsia pelo futuro, expansão de horizontes. Com a descoberta do filme-mutoscópio, o personagem engenheiro, excêntrico e misterioso, deixa um rastro que moldaria a imagem do século XX como século da modernidade.

Figura inquietante, ainda velada por sombras colaterais, com algum desconforto ocupa lugar-chave como herói do ufanismo pátrio e patrono da ciência nacional. Entre as ações ecológicas exigidas por quem investiga a vida e a obra do inventor, estaria uma expropriação do entulho autoritário que cobriu Santos Dumont com a farda da idealização orgulhosa e da glória patriótico-militar, que sonegou qualquer traço de ambiguidade e contradição em sua efígie íntima esfinge que clama por ser decifrada -, além de nublar aspectos da figura de visualidade moderna. Assim como mais de dez anos se passaram até a morte por suicídio ser revelada, outras incontinências supostamente deletérias permanecem estranhas, como a suspeita de uma doença venérea que teria contribuído para sua degeneração nervosa. A dispersão dos poluentes pode limpar os céus de brigadeiro e afastar as nuvens que cobrem outros assombros sobre o genial inventor.

A própria situação filmada já seria mote para um filme conceitual. E o foi: Santos Dumont explicando seu balão dirigível ao Honorável C. S. Rolls, filmado em Londres no ano de 1901, foi restaurado digitalmente a partir dos cartões fotográficos, fotograma a fotograma, o que permitiu restituir sua original condiçãocinema. Serviu de base para a realização de um filme experimental de found footage, Santoscópio = Dumontagem, entre 2007 e 2009, bem como para um filme-ensaio sobre found footage, Santos Dumont: pré-cineasta?, de 2007 a 2010.

No filme de 1901, Santos Dumont é cientista, professor, palestrante, prestidigitador, artista, showman, performer. ${ }^{4} \bigcirc$ filme-mutoscópio Santos Dumont explicando... flagra seu pensamento em ação - o pensamento de invenção, a invenção de seu pensamento - e deflagra o próprio processo de invenção do filme de reapropriação, que se descobre enquanto se projeta e se refaz o percurso reconstituição original e posterior recriação, por meio da reapropriação de found footage. Manifesto ou demonstração, é a imagem mental (e gestual) de uma aula de invenção.
4. Com o advento do cinema experimental de tendência estrutural, no final dos anos 1960, a vanguarda entrou na academia: filmes e artistas passaram a fazer parte do currículo das disciplinas e também do corpo docente. Ken Jacobs, Peter Kubelka e Tony Conrad são alguns dos cineastas que desenvolveram carreiras ligadas a universidades e que, coincidência ou não, cultivaram a figura de showmen, como performers do dispositivo-cinema. 
5. Universidade de São Paulo (2000, p. 27).

6. Universidade de São Paulo (2000, anexo 3, p. 5).

\section{O DISPOSITIVO SANTOS DUMONT}

Estava no grupo "Outros" da Coleção Santos Dumont do Museu Paulista da USP, como item único, o "cinedoscópio", indexado sob o código IC 13888, A2 Pr27cxc. Não havia qualquer outra identificação ou descrição da peça. No Dossiê da Coleção lia-se: "carretel de kinedoscópio com série de fotos de Santos Dumont em seu gabinete - verificar". ${ }^{5}$

Não foi possível rastrear o processo de atribuição do nome e entender o critério de catalogação. Datada de 28 de janeiro de 1935, a lista de doação dos objetos entregues ao Museu Paulista, feita por Arnaldo Dumont Villares, Jorge Dumont Villares e Ricardo Severo, sob pedido prévio de Alberto Santos Dumont, assim arrola o objeto: "70. Roda cinematographica de Santos Dumont" (Figura 1).6

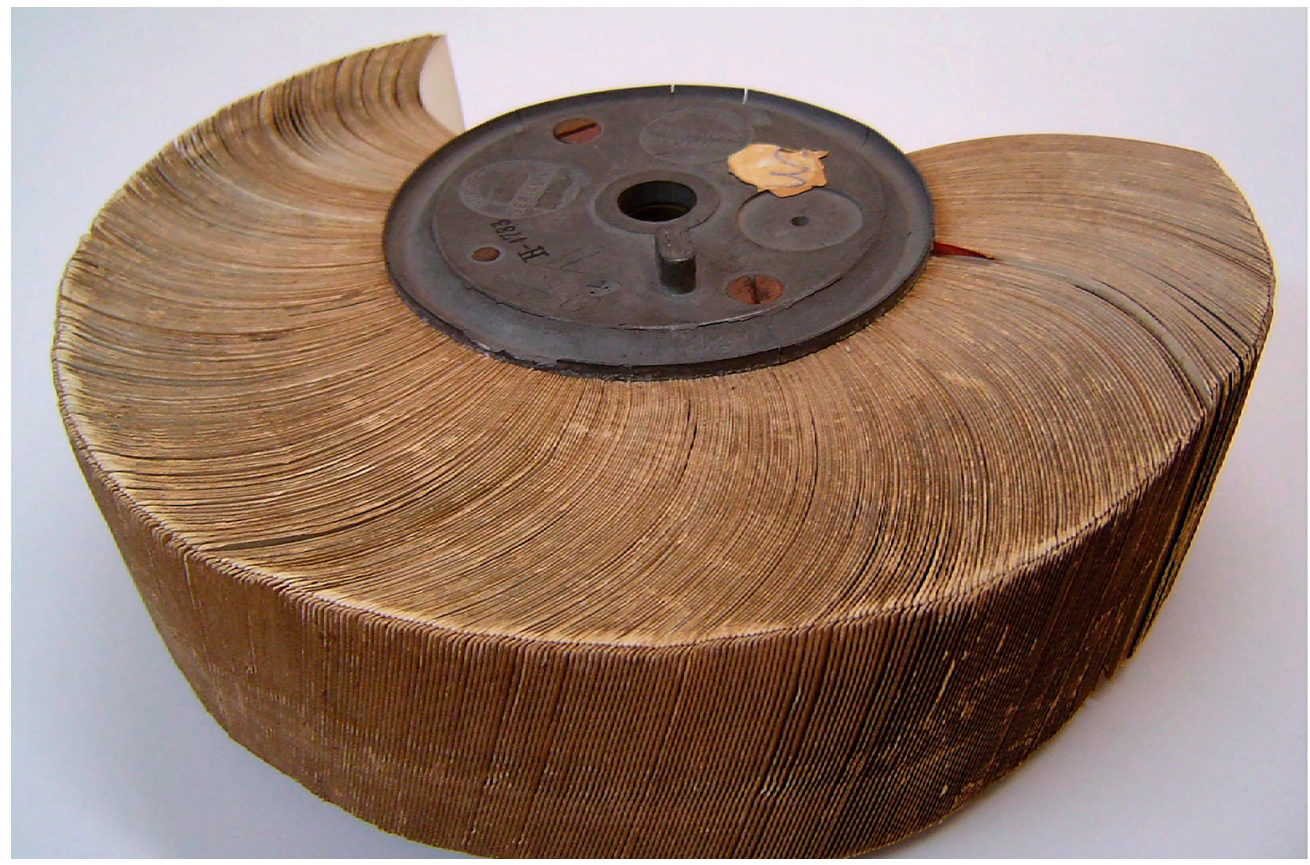

Figura 1 -Carretel do mutoscópio, 1901. Fonte: Acervo do Museu Paulista da Universidade de São Paulo. Foto: Carlos Adriano.

O nome atribuído apontava a dificuldade de identificação e o viés de construção fabular, aliás bem próprio do mito Santos Dumont. "Cinedoscópio" é uma clara referência ao kinetoscópio de Thomas Alva Edison. Desse objeto se originou o mutoscópio, algo que facilmente explicaria a transliteração e curiosamente intriga sobre o repertório de quem catalogou a peça. Os dois dispositivos têm em 
comum a visão individual do espectador, mas no de Edison o carretel não contém fotografias impressas em cartões, como no mutoscópio, e sim um rolo de película $35 \mathrm{~mm}$. Roda cinematographica seria um nome forjado por um olhar inocente, mas de significativa ressonância poética e alegórica, de raízes até arqueológicas. ${ }^{7}$

Criado por William Kennedy Laurie Dickson e Herman Casler entre 1894 e 1895, o mutoscópio é uma espécie de simplificação do kinetoscópio (18911895 ) de Edison - que Dickson ajudou a produzir, quando era colaborador de Edison -, derivado, por sua vez, do folioscópio, adaptado por Georges Demenÿ, colaborador de Étienne-Jules Marey, a partir de antigo dispositivo de exibição de imagens em série.

$\bigcirc$ carretel contendo fotos seriais é colocado verticalmente dentro de um aparelho semelhante a um módulo de metal, que proporciona a visão individual das imagens em loop, acionado por moeda e manipulado por manivela. $\bigcirc$ mutoscópio alcançou popularidade já em 1897, suplantando o kinetoscópio de Edison e banindo-o das feiras e dos parques ambulantes de diversões. As imagens eram filmadas no formato $68 \mathrm{~mm}$, "posteriormente copiadas em papel, e os fotogramas escolhidos eram colocados sobre a roda do mutoscópio". 8

Escrevendo sobre a Sala B 9 do Museu Paulista - Sala Santos Dumont -, o historiador Affonso de Taunay, diretor da instituição entre 1917 e 1945, não faz qualquer menção à peça cinematográfica, ${ }^{9}$ um estranho silêncio sobre um objeto que atrairia curiosidade no Brasil e faria boa companhia às outras peças mecânicas do inventor. Não foi possível apurar se a Sala, inaugurada em 23 de outubro de 1936, continha a peça já àquela época ou se teria sido exibida depois.

Em artigo do Jornal de Notícias de 21 de dezembro de 1932, encontrado entre os recortes do acervo do Museu Paulista, um repórter relata sua visita a "esse museu da família Santos Dumont, que certamente será recolhido ao Museu do Ipiranga [...] há filmes de alguns de seus voos e também uma fotografia movimentada do inventor em seu escritório, realizada pelo processo do rolo de papel cujas lâminas o observador vai passando como quem vira um rebolo, isto é, o pai do cinema".

A descrição mais técnica sugere um mutoscópio, mas o abrupto arroubo final ("pai do cinema") surpreende pela constatação peremptória e desconcertante, que pode induzir tanto à ideia de que o "processo do rolo de papel" antecipou o cinema como à noção de que o "inventor em seu escritório" seria o "pai do cinema". Pode ter sido determinante para tal juízo o impacto da comoção pela morte recente de Santos Dumont, com todo o cortejo no translado de seu corpo, de São Paulo para o Rio de Janeiro, em plena Revolução de 1932.
7. Para jogar mais águas ambíguas nessa roda, ou enrolar mais fita no carretel, havia ainda a chance de que o aparelho encontrado no Museu Paulista fosse um kinora, versão do mutoscópio inventada pelos irmãos Lumière após o cinematógrafo, tendo em mira o mercado doméstico. Cf. Barry (1996). Usai (2003, p. 1) cita, sem maiores detalhes, a existência de um similar: o théoscopio, do francês Théophile Lacroix.

8. Mannoni (2003, p. 422).

9. Taunay (1937, p. 95). 
10. Silveira (1945).

11. O acervo de Sophia é o conjunto de documentos organizados por seu marido, Nélson Freire Lavenère-Wanderley (1972), a partir dos recortes de imprensa coligidos pelos serviços de clipping assinados por Santos Dumont - Le Courrier de la Presse (Paris), Argus de la Presse (Paris), Press Cuttings (Londres), The Manhattan Press Clipping Bureau (Nova York).

12. Silveira (1945, p. 13).

13. Silveira (1945, p. 14).

14. Silveira (1945, p. 12).
Foi por meio de uma reportagem da Revista da Semana que se deu o primeiro encontro com a peça. ${ }^{10} \mathrm{O}$ começo do contato com o carretel foi marcado pela mediação da palavra impressa e das reproduções fotográficas, assim como sua posterior identificação. A única referência impressa com imagens do dispositivo encontrada até aquele momento foi justamente essa reportagem da Revista da Semana. Curiosamente, não há registro da matéria da Revista na Coleção Santos Dumont do Museu Paulista nem no acervo de Sophia Helena, atualmente no Centro de Documentação e Histórico da Aeronáutica. ${ }^{11}$

Destacam-se a seguir quatro passagens eloquentes da reportagem "Santos Dumont, o homem que previu o drama", de Celestino Silveira, publicada na Revista da Semana em março de 1945. São trechos que ressaltam a sala dedicada ao inventor no então chamado Museu do Ipiranga. Os dois primeiros trechos foram extraídos do texło da reportagem, e os dois seguintes funcionam como legendas das fotos ilustrativas.

Em dado momento nossa curiosidade é atraída para um objeto singular, em forma de cilindro. Aberto o mostruário dentro do qual esse objeto se encontra, nós o examinamos, e uma surpresa maior nos espera: é um ensaio cinematográfico que temos em mãos. Santos Dumont preocupava-se também com o invento de Lumière, por ocasião de suas primeiras viagens à França. E ali está o "Caleidoscópio", ponto de referência para a cinematografia de nossos dias. Centenas, se não milhares, de poses fotográficas foram batidas, com o aviador e um amigo, sentados a uma mesa. Cada pose reproduz uma atitude, e perpassando-se os pequenos quadrados das fotografias. ${ }^{12}$

Se percorrêssemos um baralho de cartas, temos a ilusão de se movimentarem as duas figuras. Santos Dumont debruça-se na mesa, abre um volume, aponta para um objeto na parede, volta-se, caminha, empunha uma bengala e a maneja, à guisa de florete. $\bigcirc$ amigo permanece sentado, apreciando-the os movimentos. É como se assistíssemos a uma projeção em câmera lenta, com o simples recurso manual, folheando as fotografias em posições sucessivas.

Infelizmente, ninguém sabe explicar a origem desse invento, nem consta, do pequeno museu Santos Dumont, qualquer esclarecimento alusivo. Mas compreende-se que a fotografia animada, em suas origens, também interessou ao homem de gênio, curioso e irrequieto, com uma centelha de espírito atilado, voltando-se para todos os atestados humanos de evolução e progresso. ${ }^{13}$

Onde se vê que até o cinema interessava a Santos Dumont. Em fins do século passado ele trabalhava no preparo de um aparelho denominado "Caleidoscópio", consistindo na sucessão de flagrantes fotográficos em número superior a mil. Eram tomadas pacientemente feitas, cada qual mostrando os personagens em rápidas mudanças de atitudes. Depois, percorrendo rapidamente as fotografias, elas davam a ilusão de movimento desses personagens. Sem dúvida, foi esse um dos pontos de referência para a descoberta do cinematógrafo. ${ }^{14}$

Pelas gravuras ao lado pode o leitor apreender melhor os movimentos manuais do "Caleidoscópio" posado por Santos Dumont e talvez inventado por ele mesmo. O pioneiro da 
aviação, em companhia de um amigo, movimenta-se ligeiramente, ao manejar, em velocidade, esses retratos. E a totalidade dos retratos constituía um cilindro, que se devia adaptar a qualquer outro apetrecho não existente no museu. ${ }^{15}$

A mera apresentação dos blocos de informação assim justapostos já é de fato eloquente. Mas deslindemos em glosa, numa espécie de digressão crítica, comentários sobre o possível sentido dessa reelaboração fabular e fabulosa, dessa história imaginada. Estaria numa revista brasileira dos anos 1940 um exemplo antecipatório da meta-história de Hollis Frampton? (Figura 2).

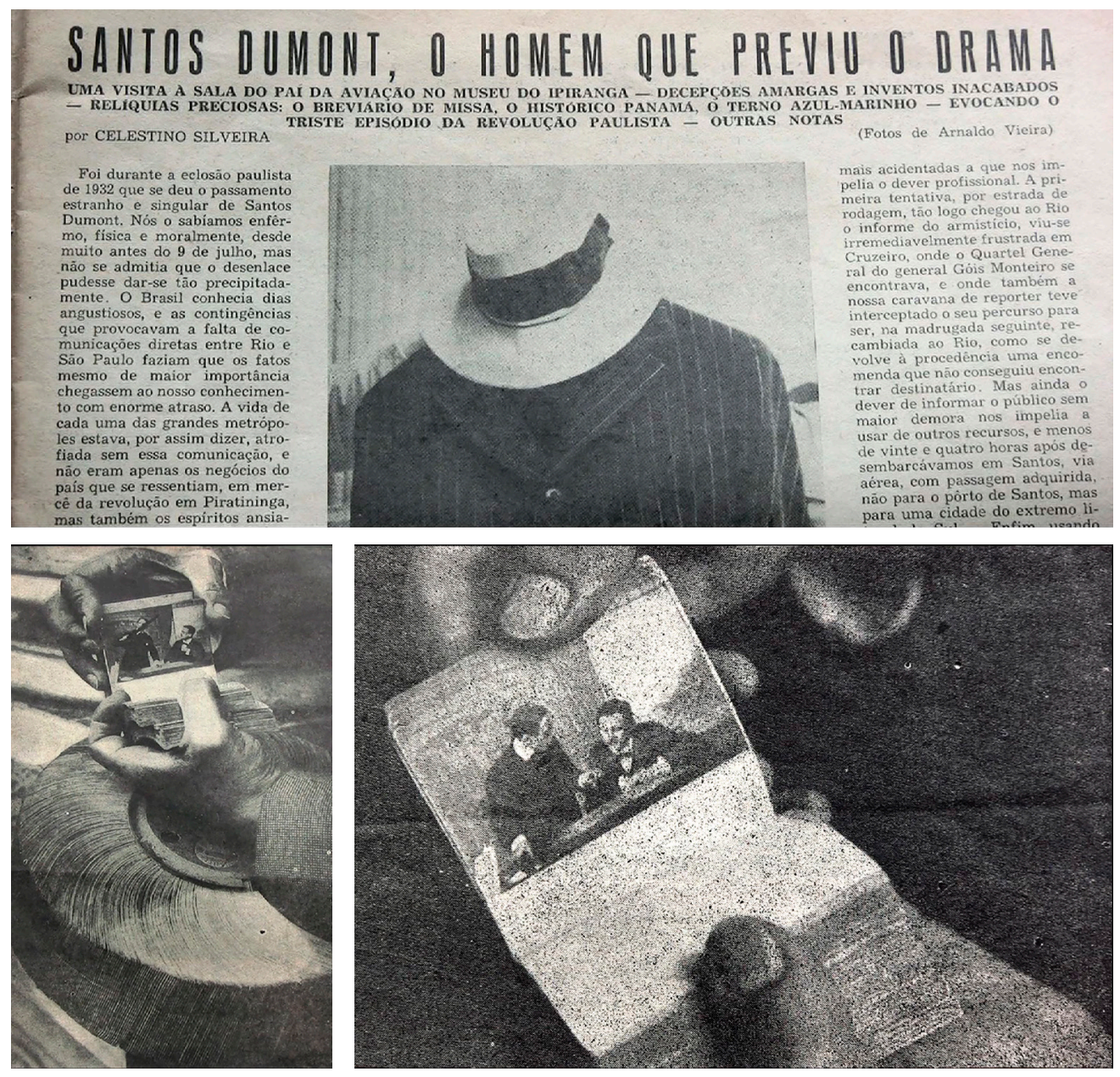

Figura 2 - Reproduções de ilustração da Revista da Semana, 1945. Fonte: Coleção particular. Cortesia: Carlos Adriano.
15. Silveira (1945, p. 13)
É relevante que a "curiosidade" faça a montagem de atrações e dirija a atenção do olhar para a peça. $\bigcirc$ "objeto singular" e circular, "em forma de cilindro", tanto pode ser o carretel de mutoscópio como o de kinora la versão doméstica do 
mutoscópio), pois ambos caberiam na vitrine do mostruário. É relevante que o exame gere "uma surpresa maior" - atração ao espírito de revelação pertinente ao encanto das vanguardas - e que a primeira descrição do objeto seja em termos tão modernos: "é um ensaio cinematográfico que temos em mãos". Quando aplicado ao cinema, ensaio é um termo que busca demarcar um estilo complexo de filmes reflexivos e associativos (tal como praticado por Jean-Luc Godard na série de filmes Histoirels) du cinéma, de 1998, entre inúmeros outros exemplos). ${ }^{16}$

A vinculação "com o invento de Lumière" denotaria uma preocupação de Santos Dumont com o cinema. A denominação "caleidoscópio" vem se juntar à constelação de nomes atribuídos ao dispositivo. Se o repórter leu "cinedoscópio" como "caleidoscópio" (se é que a peça já estava exposta com tal nome), é algo difícil de saber. $O$ parentesco com o dispositivo de Edison não é de todo despropositado: a visão individual e a exibição em loop estão na base do kinetoscópio e do mutoscópio; a diferença reside no suporte: rolo de película ou carretel de fotos. Assim, seria pertinente e sintomaticamente alegórica a licença - ou justiça - poética com referência ao objeto cilíndrico que produz, como luneta de ilusões óticas, combinações de movimentos, formas e cores a partir de fragmentos de vidro refletidos e refratários em jogos circulares de espelhos projetados no tubo.

○ caráter contemporâneo desvela-se com o espanto que ainda repercute o impacto setenta anos após o artigo - "uma surpresa maior nos espera: é um ensaio cinematográfico que temos em mãos". Também se desvela com a conclusão "ponto de referência para a cinematografia de nossos dias" e com a certeza: "sem dúvida, foi esse um dos pontos de referência para a descoberta do cinematógrafo" - tentativas de acertar o ponteiro do dispositivo com a atualidade do presente? $\bigcirc$ comentário sobre o "baralho de cartas" alude a outro objeto que estava em exposição, mas não está mais na Coleção Santos Dumont; trata-se de um flipbook ou folioscópio.

Numa das legendas, o repórter-espectador ressente-se da falta de condições ideais para visionar as imagens sob "a ilusão de movimento": "a totalidade dos retratos constituía um cilindro, que se devia adaptar a qualquer outro apetrecho não existente no museu". A desolação do repórter vazaria por sete décadas: "infelizmente, ninguém sabe explicar a origem desse invento, nem consta, do pequeno museu Santos Dumont, qualquer esclarecimento alusivo". Valendo-se do jargão diacrônico afinado à época que antecedeu o aparecimento do cinema e à conceituação histórica do trajeto das imagens em movimento, o repórter não se furta a incluir a peça no rol de atuação de Santos Dumont, sem abandonar o ufanismo positivista: a fotografia animada "também interessou ao homem de gênio, curioso e irrequieto, com uma centelha de espírito atilado, voltando-se para todos os atestados humanos de evolução e progresso". 
Mesmo considerando a função enfática na edição da página, a legenda é objetiva na conclusão: "onde se vê que até o cinema interessava a Santos Dumont". A descrição do tamanho físico - "sucessão de flagrantes fotográficos em número superior a mil" - não está incorreta: o carretel que chegou a nós tem 1.339 cartões, embora apenas 658 contenham imagem. Já o juízo de valor e de implicações é desproporcional no que se refere ao filme como "um dos pontos de referência para a descoberta do cinematógrafo", hipótese desmentida historicamente, pois o mutoscópio foi lançado após o cinematógrafo.

$\bigcirc$ artigo da Revista, além do teor de atualidade e revelação, servia como uma espécie de experiência vicária, pois afirma que "pelas gravuras ao lado pode o leitor apreender melhor os movimentos manuais do 'Caleidoscópio'", quando o leitor não tem o dispositivo à mão. Uma frase ambígua, por razões de redação ou edição, desloca Santos Dumont da posição de objeto representado na imagem para a de sujeito da ação de produzir movimento: "o pioneiro da aviação, em companhia de um amigo, movimenta-se ligeiramente, ao manejar, em velocidade, esses retratos". Como ele poderia mexer no próprio retrato? Sem ambiguidade, outra frase crucial enquadra a cena sem disfarçar a euforia: "'Caleidoscópio' posado por Santos Dumont e talvez inventado por ele mesmo".

Como em um tango, gênero de música em dois tempos, a Revista da Semana e o Jornal de Notícias afirmam um movimento de projeção alegórica, um coro em dobro que define um projeto nacional de autoestima, oscilando entre o fato e a imaginação. A (con)figuração visual da peça cinematográfica é construída por meio de palavras. Os dois artigos publicados vão além da atualidade e do registro da informação, para construir uma história, imaginar uma informação.

A peça encontrada na Coleção Santos Dumont do acervo do Museu Paulista da USP não tinha nome nem rótulo. Mas por ser um produto industrial, portava uma identificação codificada. Gravada sobre o carretel de metal há a seguinte inscrição: Patented / Nov 51895 / Jan 251898 / U. S. A. ${ }^{17}$

Como o carretel de Santos Dumont porta uma inscrição igual ao registro de outros aparelhos mutoscópios, conclui-se que o carretel pertence ao mesmo dispositivo. $\bigcirc$ filme achado foi rodado pela filial britânica da American Mutoscope \& Biograph Co., importante companhia produtora das origens do cinema; entre outros gêneros, produziu, por exemplo, filmes de D. W. Griffith, diretor que codificou a linguagem do cinema clássico.

Por meio do cruzamento de dados escavados e de extensas consultas a Paul C. Spehr, curador aposentado da Biblioteca do Congresso de Washington e especialista no cinema dos primeiros tempos (early cinema), ${ }^{18}$ foi possível fazer a identificação do filme que originou o carretel de fotografias encontrado no Museu
17. O Museu da Imagem em Movimento (MoMI), em Astoria, Nova York, tem dois aparelhos mutoscópios em exibição permanente. Durante visita em abril de 2007, foi possível fazê-los funcionar - um deles exibia Viagem à lua, de Méliès, filme que certamente seria do agrado de Santos Dumont - e conferir a gravação sobre seus corpos de metal: American Mutoscope and Biograph Co, NY / Patented Nov $51895 /$ Jan 25 1898 - Apr 261898 / Nov 221898 - Feb 141899 / Jan 26 1900. A Cinemateca Francesa, em Paris, tem um aparelho mutoscópio na exposição permanente de sua coleção Passion Cinéma: Patented Nov 5-95 / Jan 2598 - Apr 26-98 / ${ }^{\circ} 1554$.

18. Sobre o cinema dos primeiros tempos, cf. Elsaesser (1990) e Gunning (1990). 
Paulista. Spehr informou que suas anotações sobre a projeção do filme-mutoscópio de Santos Dumont vieram de uma pesquisa de Luke McKernan, scholar britânico do early cinema, sobre os programas de exibição do Palace Theatre de Londres. Numa sessão noturna de 3 de dezembro de 1901 era exibido, entre outros filmes, Santos Dumont explaining his air ship to the Hon. C. S. Rolls (Figura 3).

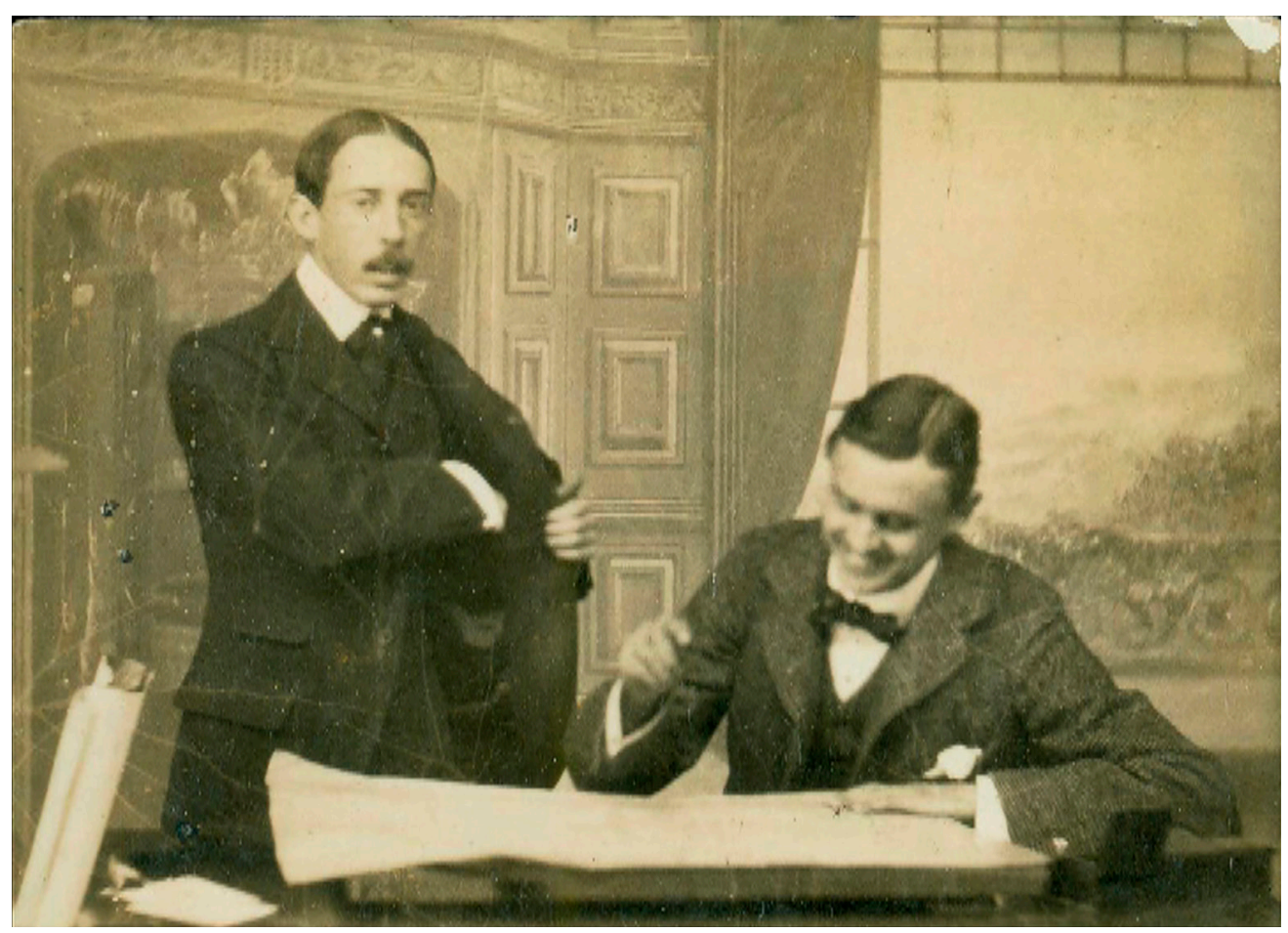

Figura 3 - Fotografia de Santos Dumont explaining his air ship to the Hon. C. S. Rolls, mutoscópio, 1901 . Fonte: Acervo do Museu Paulista da Universidade de São Paulo.

Ou seja, foi possível identificar o filme-mutoscópio de Santos Dumont por meio do registro de sua exibição. Entre agosto de 1897 e dezembro de 1902, dentro da sessão noturna da programação com números de variedade, uma seção de meia-hora era dedicada aos filmes produzidos pela American Mutoscope \& Biograph e pelas divisões britânicas e francesas da companhia. Na tela grande do Palace e de outras salas, os filmes eram exibidos em película $68 \mathrm{~mm}$ por meio do projetor Biograph. Vários deles também eram exibidos no formato peepshow, por meio do carretel de fotografias carregado no aparelho mutoscópio, distribuído em diferentes espaços públicos (saguões de teatros, de estações de trem etc.).

O contato com McKernan confirmou a indicação de Spehr sobre o filme de Santos Dumont cuja versão mutoscópio foi encontrada no Museu Paulista, e revelou ainda outro filme. Os dois filmes exibidos em sessão noturna do programa de 
variedades da Mutoscope \& Biograph no Palace Theatre, em Londres foram: Santos Dumont's aerial flight around the Eiffel Tower (primeira exibição em 11 de novembro de 1901) e Santos Dumont explaining his air ship to the Hon. C. S. Rolls (primeira exibição em 3 de dezembro de 19011.

Entre 22 e 28 de novembro de 1901, Santos Dumont esteve em Londres, homenageado pelo Aeroclube do Reino Unido em função de sua conquista do Prêmio Deutsch em outubro, quando circundou a Torre Eiffel. Foi ciceroneado pelo aeronauta Charles Stewart Rolls, futuro fundador da Rolls-Royce.

A filmagem do brasileiro explicando ao britânico o mecanismo de funcionamento e voo de seu dirigível deve ter ocorrido naquela semana. E certamente não foi no gabinete do brasileiro, como aventou a catalogação do museu, mas provavelmente no estúdio da companhia British Mutoscope \& Biograph, afiliada da American Mutoscope \& Biograph, embora se possa estranhar a ausência de registro noticioso dessa filmagem. Provavelmente foi dirigida e fotografada por William Kennedy Laurie Dickson, que àquela época dirigia a unidade londrina da companhia. A duração do filme reconstituído, na velocidade de trinta quadros por segundo, ficou em 43 segundos e 26 fotogramas.

\section{GENEALOGIAS DA RECICLAGEM E REAPROPRIAÇÃO DE ARQUIVO}

Produto da restauração do filme-mutoscópio de 1901 encontrado no Museu Paulista, o filme experimental Santoscópio = Dumontagem pertence ao "gênero" do found footage. Sem pretensões de fazer história ou de definir taxativamente um assunto tão complexo, esta seção do artigo se limita a apresentar um resumo de taxonomia dos filmes que reciclam imagens alheias.

A apropriação artística de objetos do cotidiano utilitário ou da própria história da arte que, assim deslocados de seu contexto original, assumem novos sentidos, não é fenômeno inédito nem recente. Porém, sua frequência e incidência fazem parecer fato exponencial e explícito, com a fragmentação das fronteiras do mundo e a disseminação das plataformas digitais de distribuição e exibição de "conteúdos".

Reapropriação é quase efeito sinônimo e feito sincrônico à instauração do moderno. No ano da Revolução Russa, Duchamp deslocou um urinol do ambiente do banheiro e o colocou na ambiência da galeria de arte sob o singelo título Fonte, e cometeu assim uma das primeiras apropriações, conscientes e irônicas: transformar um prosaico objeto cotidiano em provocadora obra de arte pelo gesto do deslocamento. 
19. Leyda (1971, p. 13).

20. Wess (1993, p. 35).

21. Leyda (1971, p. 23-28)

22. Sobre found footage, $\mathrm{cf}$. Adriano (2015).

23. Brenez; Chodorov (2015, p. 2).
Uma genealogia da apropriação no cinema remeteria ao cinema das origens (early cinema). Leyda ${ }^{19}$ e Wees ${ }^{20}$ apontam usos rudimentares aplicados à: (1) projeção de filmes, como a adição de planos alheios ao filme Lumière sobre Dreyfus quando exibido pelo distribuidor Francis Doublier em 1899; (2) produção de filmes, como em The life of an American fireman (Edwin S. Porter, 1902).

Ao longo da história do cinema, o filme de imagens reutilizadas foi tratado de maneiras diferentes. Um gênero (pre)dominante é o da compilação histórica dos documentários de arquivo. Esfir (Esther) Schub, montadora ligada a Dziga Vertov, é matriz fundadora da montagem com material de arquivo, no âmbito da compilação, graças a filmes como A queda da dinastia Romanov (Padenije dynastii Romanovych, 1926), A grande estrada (Velikiy put, 1927) e A Rússia de Nicolau Il e Leon Tolstoi (Rossiya Nikolaya II i Lev Tolstoy, 1928). ${ }^{21}$

O cinema, como expressão da modernidade no século XX e forma artística que influenciaria outras artes, tem em sua vertente de vanguarda o found footage (reapropriação de arquivo), forma de produção cinematográfica que, como gênero ou procedimento, recicla, reedita e ressignifica imagens alheias, filmadas em outro tempo e outro contexto, a partir da manipulação e da montagem do material fílmico, e depois transpostas para um novo tempo e um novo contexto. ${ }^{22}$

A retomada do arquivo como base para a (re)criação fílmica viria com a vanguarda americana no final da década de 1950. O found footage recicla, redefine, reprocessa, ressignifica, por associação ou intervenção, imagens alheias. A montagem associativa de Bruce Conner - A movie (1958), Cosmic ray (1961), Mongoloid (1978) - foi antecipada por Joseph Cornell, artista plástico da colagem que projetou de suas caixas de luz a cinefilia de Rose Hobart (1939). O gênero found footage se cristalizaria nas estratégias minimais do cinema de viés estrutural, com Ken Jacobs (Tom Tom the piper's son, 19691971; Perfect film, 1986; New York ghetto fishmarket, 1903, 1992; The Georgetown loop e Disorient express, 1996), Ernie Gehr (Eureka, 1974) e Hollis Frampton (Public domain, 1972; Gloria!, 1979).

A preciosa cartografia de Brenez e Chodorov propõe, com rigor analítico, duas formas principais de apropriação. A "apropriação intertextual" é calcada in re e não se refere à refilmagem de um original seguindo-o quadro a quadro, sem uso de material já filmado, como Segundo de Chomon em Voyage dans la lune (1909) segue o filme homônimo de Méliès (1902), ou como Gus Van Sant em seu Psycho (1999) sobre uma suposta clonagem de Hitchcock (1960). A outra forma de apropriação é a "reciclagem", decalcada na "recuperação in se", que comportaria duas formas. ${ }^{23}$ 
A "reciclagem endógena" se aplica ao trailer e à "autossíntese", quando o artista utiliza fragmentos de seus próprios filmes "biográficos", como Film portrait (Jerome Hill, 1970) e Un film (Marcel Hanoun, 1983). A "reciclagem exógena" se aplica às várias formas de citação ou alusão. Brenez e Chodorov destacam três modalidades: 11 ) stock footage - filmes B americanos que inserem planos de outras produções para compensar falhas de continuidade ou falta de tomadas de ação; (2) filmes de montagem - "coleção ilustrada" de imagens já filmadas, como crítica das atualidades (caso do já aludido A queda da dinastia Romanov) ou ensaio (Nosso século, Artavazd Pelechian, Nash vek, 1982); e (3) found footage concentração na manipulação do material fílmico, tornando as imagens autônomas e apontando para novas esferas e formas de montagem. ${ }^{24}$

Continuando, como num lance mallarmaico, nas exaustivas subdivisões prismáticas de suas ideias - curiosamente a indicar a pluralidade de reflexos e refrações naturais do arquivo que se projetam da tentativa taxonômica - os autores propõem cinco usos principais de found footage: elegíaco, crítico, estrutural, materiológico e analítico.

uso elegíaco fragmenta o original para guardar instantes específicos, que viram objetos de fetiche e fazem aparecer o leitmotif: Rose Hobart Uoseph Cornell, 1939) com a atriz Rose Hobart ( 193 1); Her fragrant emulsion (Lewis Khlar, 1987) com Mimsy Farmer.

○ uso crítico predomina; parte de imagens industriais ou privadas para destruílas, por quatro operações: anamnese, desvio, variação/exaustão e ready-made.

- Na anamnese, justapõem-se "imagens de uma mesma natureza de modo a fazêlas significar não algo diferente do que elas dizem, mas precisamente aquilo que elas mostram e que nos recusamos a ver" (L' histoire du soldat inconnu, Henri Stork, 1931; A movie, 1958, e Report, 1967, Bruce Conner);25

- No desvio, é o détournement da Internacional Situacionista (La société du spectacle, Guy Debord, 1973):26

- Na variação/exaustão, "concentra-se em um único objeto fílmico, e trata de criar variações sobre ele, até o ponto de esgotar suas potencialidades pela introdução de um ou vários parâmetros plásticos (visuais ou sonoros)" (Lettre de Sibéria, Chris Marker, 1958; The politics of perception, Kirk Tougas, 19731;

- No ready-made remonta-se ao gesto de Duchamp, apropriando-se do objeto sem alteráto (Perfect film, Ken Jacobs, 1986; Chutes e Une oeuvre, Maurice Lemaître, 1968). ${ }^{27}$

O terceiro uso é o estrutural, cuja norma é "elaborar um filme não a partir de um motivo, mas de uma proposta, de um protocolo que diz respeito ao próprio cinema" (Berlin horse, Malcolm LeGrice, 1970). ${ }^{28}$
24. Brenez; Chodorov (2015, p. 3).

25. Brenez; Chodorov (2015, p. 4).

26. Brenez; Chodorov (2015, p. 5).

27. Brenez; Chodorov (2015, p. 6).

28. Brenez; Chodorov (2015, p. 7). 
29. Brenez; Chodorov (2015, p. 8).

30. Brenez; Chodorov (2015, p. 9)

31. Brenez; Chodorov (2015, p. 10).

32. Brenez; Chodorov (2015, p. 11).

33. A "flicagem" reproduz o efeito de uma espécie de alternância estroboscópica, em que a sequência de imagens em movimento parece piscar para o olhar.
Quanto ao uso materiológico, explora a substância material da película: a "química da emulsão" (filmes de Carl Brown); a decomposição "do fotograma em camadas e subcamadas" (filmes de Cécile Fontaine); o tratado sobre o formato em Standard gauge (1984, Morgan Fisher). ${ }^{29}$

O uso analítico comporta quatro modos de operação do estudo visual: glosa, montagem cruzada, variação analíitica, síntese entre montagem cruzada e variação analííica. ${ }^{30}$

- Caso de glosa, Erich von Stroheim (1979) traz na trilha sonora comentários de admiração de Maurice Lemaître sobre Stroheim em cima de imagens de Foolish wives (Stroheim, 1922).

- A montagem cruzada sobrepõe imagens, como fazem Al Razutis (Visual essays, 1973-1984) no Canadá; Godard (Histoire(s) du cinéma, 1978-1998) na França; Bill Morrison (Decasia, 2002) nos Estados Unidos; Gustav Deutsch (Film ist, 1998) na Áustria". ${ }^{31}$

- A variação analítica é um "tratado das formas do movimento (como trajeto objetivo, passagem e circulação psíquica), nas imagens e entre as imagens", cuja síntese monumental é a morfologia da imagem em Tom Tom the piper's son de Ken Jacobs (1969-1971).

- Na síntese entre montagem cruzada e variação analítica estão os filmes de Yervant Gianikian e Angela Ricci Lucchi, que restituem "uma outra dimensão, complexa e sutil: sua natureza histórica", "através de refilmagem (de imagens que eles próprios restauraram), de ralentações e de cromatizações".

Para Brenez e Chodorov, ${ }^{32}$ Outer space (Peter Tscherkassky, 1999) é uma aglomeração de todos procedimentos, usos e efeitos aqui descritos. Os aspectos crítico (em suas versões de anamnese e variação/exaustão), estrutural, materiológico e analífico (em suas subdivisões de montagem cruzada, variação analíitica e síntese) são referências importantes para o filme de found footage originado do filmemutoscópio de Santos Dumont.

Em Santoscópio = Dumontagem estão definidos dois parâmetros formais e conceituais fundantes, em termos de uma metodologia poética, para a estruturação das imagens, que são próprios do dispositivo mutoscópio: o loop e o flicker. $\bigcirc$ mecanismo de exibição que alterna cartões fotográficos portando imagem e cartões brancos ou pretos (sem imagem), produzindo o efeito da flicagem, ${ }^{33}$ necessário à mecânica visual do dispositivo mutoscópio, gera em Santoscópio = Dumontagem dimensões estruturais de refrações, ilusões e projeções de movimentos. $\bigcirc$ mecanismo de exibição contínua, em "circuito fechado", proporcionado pelo formato em anel do carretel de 1901, que faz com que o movimento continue em ação de ciclo, 
inspira os giros, as cadeias e cadências de reiteração e repetição de movimentos e gestos no filme de reapropriação de 2010 (Figura 4).

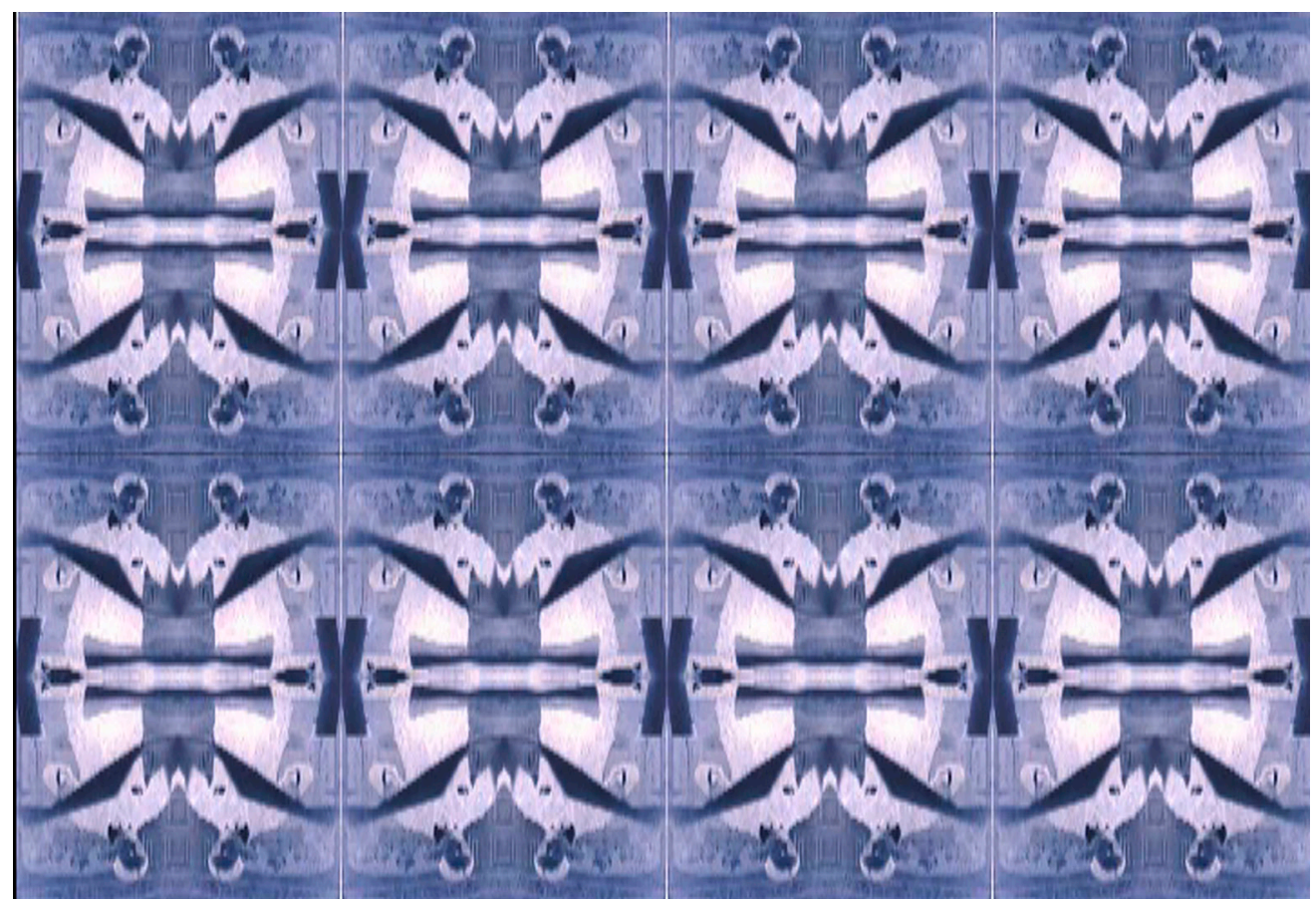

Figura 4 - Fotograma de Santoscópio = Dumontagem, filme 35mm, 2010. Fonte: Coleção particular. Cortesia: Carlos Adriano.

PROJEÇÕES DA IMAGEM: META-HISTÓRIA, RUÍNAS E FANTASMAS

A meta-história de Hollis Frampton é um artifício ético-estético que permitiria ao artista continuar compondo seus trabalhos de modo que ainda se justificassem tanto o seu projeto pessoal quanto a pertinência de sua atuação em dado meio artístico. A partir de uma linhagem à la Jorge Luis Borges, ${ }^{34}$ elegem-se parâmetros de formação para um programa poético. As novas obras se articulariam com as obras antigas numa constelação de invenção, em temporalidades até anacrônicas (se assim o projeto o conclamar), um arquivo infinito de imagens e sons destinado a inseminar consistência ressonante no seu processo de produção. Segundo o cineasta Hollis Frampton, que articulou o conceito,

[O] metahistoriador do cinema se ocupa com a invenção de uma tradição, isto é, um conjunto coerente e manejável de monumentos discretos, a fim de inseminar consistência ressonante no corpo crescente de sua arte.
34. Como pode ser visto em "Kafka e seus precursores" (BORGES, 2007, p. 127-130). 
35. Jenkins (2009, p. 136).

36. Carroll (1986-1987, p. 200).

37. Carroll (1986-1987, p. 204).

38. Carroll. Loc. cit.

39. Carroll. Loc. cit.

40. Carroll. Loc. cit.
Tais obras podem não existir, e então é seu dever fazê-las. Ou elas podem já existir, em algum lugar fora do perímetro intencional da arte [...]. E então ele deve refazê-las. ${ }^{35}$

A construção da tradição dinâmica de Frampton através da investigação e recontextualização de textos históricos é facilitada pelo trabalho tanto do artista como do arquivista, condensados na figura do meta-historiador. Noël Carroll nos lembra que a meta-história de Frampton é, em primeiro lugar e antes de tudo, importante por ser "artisticamente geradora". Carroll sugere que Frampton desenvolveu a noção de meta-história para reconciliar produtivamente duas abordagens opostas de teoria do cinema e crítica de arte dos anos 1960, 1970 e 1980 que foram centrais para o pensamento de Frampton: "a abordagem essencialista e a abordagem histórica". ${ }^{36}$

Carroll ${ }^{37}$ sugere que Frampton se volta para a uma teleologia invertida que faz do artista um meta-historiador ativo:

O metahistoriador do cinema, mesmo que aberto à história do cinema, não vê a história do cinema como convergindo para o presente. A história do cinema de fato é híbrida; não há um destino inscrito nela. Em vez disso, agora, no presente, o metahistoriador dá conta da desordem da história do cinema e almeja certas condições do meio, que the parecem representar sua quintessência. ${ }^{38}$

crítico continua:

na história do cinema propriamente dita [...] tais condições não foram de fato exploradas rigorosa e autoconsciemente. Torna-se tarefa do metahistoriador compensar esta falha, para visualizar a história do cinema como teria sido caso esta fosse rigorosamente autoconsciente, para então reconstrút-la "axiomaticamente". O cineasta metahistoriador imagina como a história do cinema deveria ter sido (de acordo com seus critérios), e então segue adiante para realizá-la. ${ }^{39}$

E conclui, entre os interstícios retrospectivos e prospectivos:

Pois a conceituação teórica de Frampton foi planejada para sustentar sua sobrevivência como cineasta - não no sentido de subsistência material, mas como forma de manter a continuação de seu trabalho criativo. ${ }^{40}$

Em seu ensaio sobre a meta-história, Frampton procedeu à conceituaçãochave de "um cinema infinito", que projeta sua materialidade para além do sistema, e, numa outra visão-intervenção, acomodaria o ideal de um arquivo infinito:

Antes da invenção da fotografia estática, os fotogramas do cinema infinito estavam vazios, uma ponta em branco, então umas poucas imagens começaram a aparecer sobre uma fita de filme sem fim. Desde o nascimento do cinema fotográfico, todos os fotogramas são 
preenchidos com imagens. Não há nada na lógica estrutural da tira de filme de cinema que impeça seqüestrar-se uma única imagem qualquer. Uma fotografia estática é simplesmente um fotograma isolado e retirado do cinema infinito. ${ }^{41}$

A descoberta, a restauração ${ }^{42}$ e a reinvenção do filme-mutoscópio de Santos Dumont permitem que se configure a hipótese de um meta-historiador-artista aplicado ao contexto brasileiro. Ele trabalharia com aqueles restos materiais, com os vestígios esquecidos ou desconhecidos da cultura de artefatos nacional, no sentido não apenas de resgatá-los para a história, mas também de reinventá-los para a vida, num mesmo gesto e impulso (de pesquisa e de criação), inseminando "consistência ressonante" nos campos da arte e da história. E o fato de o filmemutoscópio de Santos Dumont ser um raro exemplo brasileiro - um elo perdido? - do "cinema de atrações" das origens do cinema reveste ainda mais a hipótese de ressonância do meta-historiador-artista.

Produto da restauração do filme-mutoscópio encontrado no Museu Paulista, o filme experimental Santoscópio = Dumontagem recria o mundo do "cinema de atrações", conceito de Tom Gunning e André Gaudreault, ${ }^{43}$ informado pela "nova história do cinema", que, a partir do Congresso da Federação Internacional dos Arquivos de Filmes (Fiaf) em Brighton (1978), avaliou o "cinema dos primeiros tempos" ou "cinema das origens" (early cinema) em outros termos, não só por textos (filmes), mas por contextos (documentos diversos, como programas de exibição, solicitações de patentes etc.). ${ }^{44}$

Sob a chave da "estética do espanto", 45 o "cinema de atrações" é um cinema de relação direta com o espectador, que o interpela sem o recurso da absorção narrativa ou da ilusão diegética. Seu tr(i)unfo está na potência que envolve seu ato básico: mostrar, e não narrar, incitando a curiosidade visual. Em Santos Dumont explicando..., o brasileiro olha diretamente para a câmera le, por extensão, para o espectador) por duas vezes.

Reciclando os primórdios do cinema em base digital (montagem e edição de material filmado foto-química-mecanicamente), do found footage ao database, configura-se uma hipótese paratática, que caberia na perspectiva meta-histórica do arquivo: "O cineasta do banco de dados". ${ }^{46}$ Correlata, desdobra-se a substituição de qualquer coleção de informações culturais, como museu e biblioteca, pela base de dados do computador. ${ }^{47}$ Se Mallarmé achava que o mundo existia para acabar em livro, o mundo acabou mesmo em YouTube, como consta do poema "Tvgrama 4 - Erratum". ${ }^{48}$

A ruína é a evidência dos restos do tempo. $\bigcirc$ cinema de reapropriação re(in) staura a experiência das ruínas. Achar a imagem filmada é reprocessar o tempo reencontrado. Pensar o tempo como montagem de elementos heterogêneos: justa
41. Jenkins (2009, p. 134).

42. Reinvenção consignada em Santoscópio = Dumontagem. Cf. La Ferla (2014).

43. Gunning (1995); Strauven (2006).

44. Rosa (2008).

45. Gunning (1995, p. 52).

46. Manovich (2001, p. 239).

47. Manovich (2001, p. 217).

48. Campos (2015, p. 36-37). 
49. Reverdy (1918, p. 1).

50. Jenkins (2009, p. 131139). Publicado originalmente em Artforum, New York, v. 10, n. 1, set. 1971.

51. Moore (2006, p. 67).

52. Benjamin (1984, p. 200).

53. Benjamin (2006, p. 504).

54. Xavier (2012, p. 457).

55. Xavier. Loc. cit.

56. Xavier (2012, p. 445). posição poética. Aproximação de realidades distantes: "quanto mais as relações entre duas realidades (assim aproximadas) forem distantes e justas, mais forte será a imagem - maior será sua potência emotiva e sua realidade poética" ${ }^{49}$ Daí a graça e o assombro do encontro, do material encontrado. Como síntese apropriada e poética para uma prática de cinema, cito uma feliz formulação de Rachel Moore em análise do filme (nostalgia) de Frampton, produzido no mesmo ano do ensaio sobre a meta-história, ${ }^{50}$ formulação que funciona também como justificativa para uma alegoria da meta-história: "criar ruínas é o trabalho da sobrevivência". ${ }^{51}$

Uma das experiências mais instigantes e originais na abordagem da história como reimaginação (e reconfiguração, e refundação) da memória - e, portanto, referência basilar para o cinema de reapropriação de arquivo (found footage) - é o pensamento de Walter Benjamin, com sua formulação seminal: "As alegorias são no reino dos pensamentos o que são as ruínas no reino das coisas.". 52

Sob a perspectiva da história do ponto de vista dos vencidos, Benjamin recolheu os cacos da história para (des)construir um monumento em ruínas, articulou as noções de ruína e de perda na elaboração de uma imagem que, antes de representar, pudesse sobretudo configurar esse momento da memória como uma constelação. Os termos da equação implicados da imagem-dialética são iluminadores na relação entre os tempos que a imagem configura:

Não se deve dizer que o passado esclarece o presente ou que o presente esclarece $\circ$ passado. Uma imagem, ao contrário, é aquilo em que o Outrora encontra o Agora num relâmpago, para formar uma constelação. Em outras palavras, a imagem é a dialética em suspensão. ${ }^{53}$

Benjamin é referência, "dada sua posição na recuperação da alegoria para se pensar a arte moderna". ${ }^{54}$ Mas requer cautela a aproximação:

Boa parte do que se fala sobre a alegoria no cenário contemporâneo é uma retomada particular, temperada pelas modernas teorias da linguagem, que radicaliza o diagnóstico da "crise de representação", fazendo uma ligação entre alegoria, opacidade e "suspensão do sentido" que não corresponde às ideias de Benjamin. ${ }^{55}$

"A noção de alegoria aparece muito no discurso sobre a arte contemporânea" e pode caracterizar "formas de construção e de montagem" da imagem, tomando a alegoria como modo de representação. A "estratégia alegórica é então abordada em dois aspectos: o da descrição da textura e estrutura da obra e o da discussão da postura do artista diante da sociedade". 56 Seria possível também pensar a postura do artista diante da história, o que permitiria uma passagem da alegoria com a meta-história de Frampton aplicada ao found footage. 
A "caracterização formal da alegoria" fornecida por Angus Fletcher ${ }^{57}$ "mostra a descontinuidade e a justaposição apontadas pela matriz da modernidade" ${ }^{58}$ o que remeteria aos processos tanto do cinema de reapropriação de imagens de arquivo como de pesquisa de uma peça museológica como o carretel de mutoscópio de Santos Dumont: "o traço que Fletcher acentua como próprio à alegoria é o caráter descontínuo da organização das imagens", e "o discurso tipicamente alegórico apresenta brechas, lacunas" que dispõem o espectador "numa postura analítica em que qualquer enunciado fragmentado assume a aparência de mensagem cifrada que solicita o deciframento". ${ }^{59} \bigcirc$ found footage e o mutoscópio de Santos Dumont abrem-se numa mesma clave:

em sua incompletude e justaposições, a alegoria [...] traz a marca do inacabado, do trabalho minado por acidentes de percurso, por imposições, truncamentos de toda ordem, tudo o que assinala o quanto a obra humana se dá no tempo, tudo o que testemunha o quanto [...] o caminho entre a experiência particular e o objeto que a cristaliza tem elementos mediadores, sofrem a incidência da linguagem e de suas convenções. ${ }^{60}$

Santos Dumont explicando... termina com um gesto incompleto do inventor brasileiro. Com a mão direita, ele faz o movimento de loop lo dedo indicador descrevendo uma trajetória circular) que não se completa em seu circuito fechado: o filme acaba antes de perfazer a volta total.

Como operação histórica e de linguagem, que atua na história por meio da linguagem e atua na linguagem por meio da história - adensando a metahistória de Frampton -, a reapropriação found footage, ao promover a montagem de materiais e de tempos heterogêneos, é imantada (encantada) pelo mistério como o do mutoscópio de Santos Dumont (em sua espessura de objeto, em sua textura do que representa e apresenta): "a própria disjunção enfática dos termos (como na colagem) pode ser estratagema para realçar a ambiguidade, o enigma". ${ }^{61}$

Seria possível ler o carretel de mutoscópio de Santos Dumont como emblema dessa alegoria das ruínas. E não apenas porque o carretel encontrado no Museu Paulista estava partido. Sua forma circular remeteria ao anel da constelação do céu, ao voo do circuito fechado do avião e ao Cinéorama de Raoul Grimoin-Sanson instalado na Exposição Universal de Paris em 1900 portanto, o loop das imagens no próprio dispositivo e das ressonâncias que articula. A reposição da peça dispõe o encontro do outrora com o agora - o outro agora, o outro no agora, o agora outro. Na configuração de uma constelação, o passado e o presente articulam-se em fulguração.

A alegoria de Benjamin - "as ideias se relacionam com as coisas como as constelações com as estrelas" 62 - encontraria sintonia na forma de pensamento de
57. Em Allegory: the theory of a symbolic mode, publicado em 1964.

58. Xavier (2012, p. 38).

59. Xavier (2012, p. 446).

60. Xavier (2012, p. 456).

61. Xavier (2012, p. 39).

62. Benjamin (1984, p. 56). 
63. Hofmann apud Michaud (2013, p. 296).

64. Gombrich (2015, p. 230).

65. Didi-Huberman (2013, p. 206).

66. Michaud (2013, p. 296).

67. Michaud (2013, p. 9).

68. Michaud (2013, p. 240).

69. Didi-Huberman (2013, p. 43).

70. Gertrud Bing apud Michaud (2013, p. 23).

71. Xavier (2012, p. 459).

72. Didi-Huberman (2013, p. 293-294).

73. O que provém de Bachelard (1988, p. 183): "Toda forma guarda uma vida. O fóssil [já] não é mais simplesmente um ser que viveu, [mas] é um ser que vive ainda, adormecido na sua forma".
Aby Warburg, que estudou as imagens da astrologia antiga e suas ressonâncias nas imagens artísticas. Os elementos em seu atlas Mnemosyne eram organizados como "constelações". 63

Arquivista convulso e compulsivo, Warburg tratou o saber como arquivo. As imagens coligidas por ele em Mnemosyne - em que compara reproduções de obras de arte e de documentos de diversas épocas, produzindo uma nova maneira de fazer história da arte - seriam "engramas". Engrama é o traço deixado por todo acontecimento que afeta uma matéria viva, na definição de Richard Semon, discípulo do psicólogo Ewald Hering, cujo artigo "A memória como função geral da matéria organizada" tanto encantou Warburg. Um engrama guarda assim uma energia mnêmonica ${ }^{64}$ e pode também ser lido como "imagem-lembrança"65 e como fotograma. ${ }^{66}$

Com seu atlas de imagens, Warburg instituiria "uma verdadeira metodologia de montagem do 'filme' na história da arte", ${ }^{67}$ que conversaria com a montagem de atrações do cinema das origens e a de Serguei Mikhailovitch Eisenstein. Warburg chamou seu procedimento operacional de "iconologia dos intervalos", 68 que, por sua vez, els)coaria na montagem de Dziga Vertov.

"Imagem sobrevivente" é um conceito-chave de Warburg. Ele entendia a história da arte como sobrevivência de formas - no caso, da Antiguidade no Renascimento. A "imagem sobrevivente" (nachleben) implica "a permanência de motivos antigos na arte de tempos posteriores. ${ }^{69}$ Outro conceito de Warburg poderia ser transladado para o movimento gestual do "cinema de atrações": "fórmula de pathos" (pathosformel) - "expressões visíveis de estados psíquicos que as imagens teriam fossilizado". 70

E não seria aquele carretel de mutoscópio, adormecido numa seção chamada "Outros", um fóssil, uma ruína? Na ruína há "um depósito da temporalidade disposto numa imagem (simulânea); nela, o tempo atua como erosão, de fora para dentro". ${ }^{71}$ Na formulação do leiffossil - "a sobrevivência como memória psíquica passível de corporalização - e da imagem sobrevivente, Warburg trabalha os tempos enterrados, o fóssil como a "vida adormecida em sua forma"72 (Figura 5). ${ }^{73}$

No filme-mutoscópio de Santos Dumont a atração é seu pensamento em ação, assim como sua performance é motivo para a câmera, e o são os códigos de rituais de gesto do "cinema de atrações" encapsulados no filme. Ressoando seu corpo em voo, tantas vezes em risco mesmo de sobrevivência, quais energias mnemônicas estavam guardadas naquele carretel adormecido no museu? Quais engramas o filme-mutoscópio de Santos Dumont projetaria?

Pensando sobre Mnemosyne, "meses antes de morrer" o historiador de arte Aby Warburg afirmava "que a história das imagens deve ser compreendida 


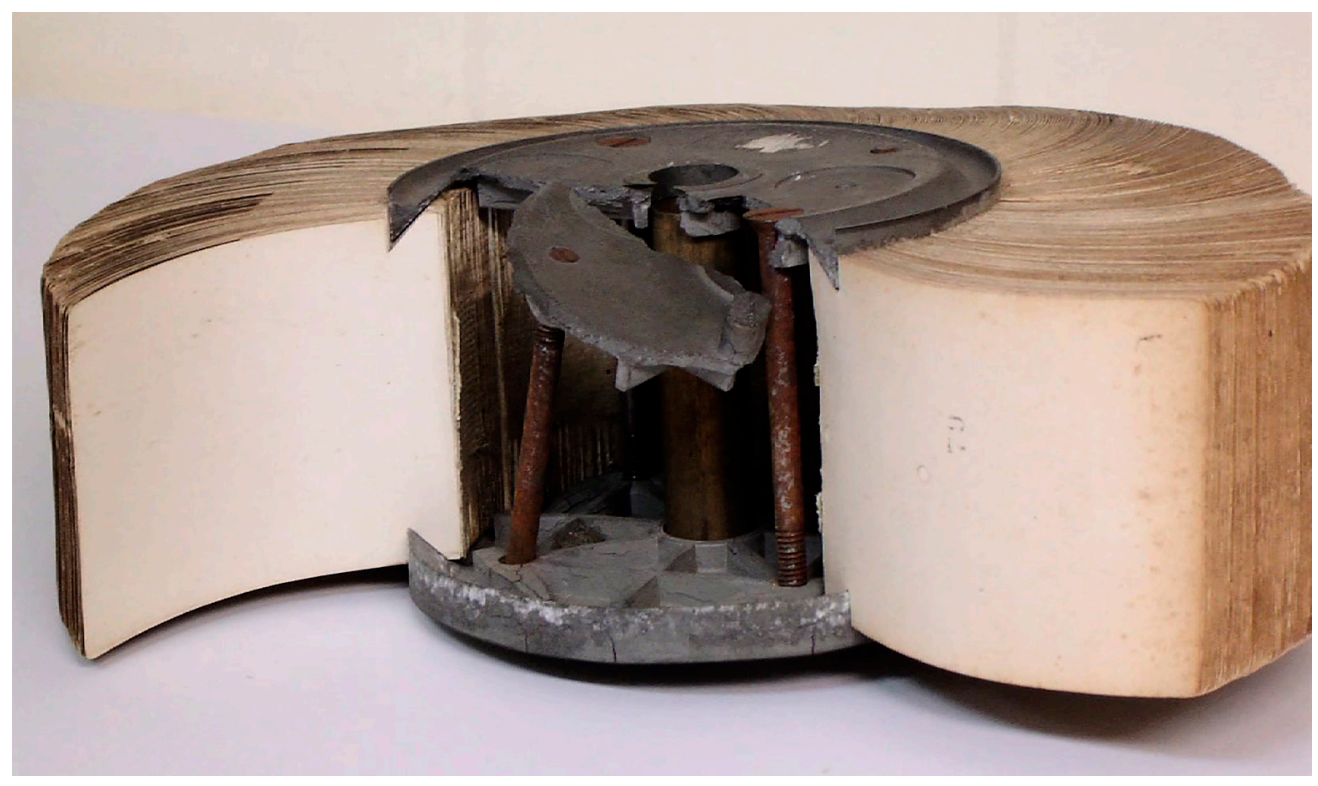

74. Didi-Huberman (2013, p. 426).

75. Gombrich (2015, p. 265).

76. Yerushalmi (1991).

77. Derrida (2001).

78. Derrida (2001, p. 60).

Figura 5 - Carretel do mutoscópio, 1901. Fonte: Acervo do Museu Paulista da Universidade de São Paulo. Foto: Carlos Adriano.

como uma 'história de fantasmas para gente grande'". 74 Para ele, "a filosofia da Mneme parecia justificar a esperança de que essa 'história de fantasmas para gente grande' só poderia ser contada unicamente em imagens". ${ }^{75}$ "Espectros e remanescências da imagem sobrevivente" poderia ser um mote para os filmes de found footage e para a operação envolvida ao redor do filme-mutoscópio de Santos Dumont.

Uma invenção extemporânea, talvez menos inapropriado que dizer "anacrônica", é a do "monólogo com" (o fantasma). É o expediente do Monólogo com Freud de Yerushalmi, ${ }^{76}$ livro cujo final tanto encantou Derrida em seu sintomático Mal de arquivo, 77 mas que caberia tão bem na compilação Mortes imaginárias de Schneider e no filme found footage. Eis a reprodução do monólogo de Yerushalmi com Freud: ${ }^{78}$

Quando sua filha [Anna] fez chegar esta mensagem [sobre a acusação de que a psicanálise seria uma "ciência judia"] ao Congresso de Jerusalém, era em seu nome que ela se exprimia? / Eu the peço, prezado professor, diga-me, prometo guardar o segredo.

E conclui Derrida: "Estas são as últimas palavras do livro. Tudo parece selado por esta última assinatura em forma de promessa".

Seduzido pelo dispositivo Yerushalmi, Derrida aposta na promessa de um método de imagem: 
79. Derrida (2001, p. 54).

80. Derrida (2001, p. 55).

81. Derrida (2001, p. 110)

82. Didi-Huberman (2013, p. 424).

83. Didi-Huberman. Loc. cit. No original: Full fathom five thy father lies; Of his bones are coral made; Those are pearls that were his eyes:/ Nothing of him that doth fade/But doth suffer a sea-change/Into something rich and strange. se o scholar clássico não acreditava em fantasmas e na verdade não sabia como falar a eles, proibindo-se mesmo de fazê-lo, poderia bem ser que Marcelo [abertura de Hamlet] tenha antecipado a chegada de um scholar do futuro, de um scholar que no futuro, e para pensar o futuro, ousaria falar com o fantasma. De um scholar que ousaria confessar que ele sabe falar com fantasmas, pretendendo mesmo que isso não contradiga nem limite sua scholarship mas que, ao contrário, a tenha condicionado à custa de alguma complicação ainda impensada que viesse dar razão ao outro, isto é, ao fantasma. ${ }^{79}$

dispositivo Yerushalmi parece apropriado para a reapropriação de arquivo:

esta ficção tem uma outra originalidade que põe a ficcionalidade do "monólogo" como que em abismamento [en abyme]: a apóstrofe é dirigida a um morto, ao objeto do historiador transformado em sujeito espectral, destinatário ou interlocutor virtual de um tipo de carta aberta. Outro efeito de arquivo. Em sua própria ficção, esta apóstrofe vem de fato enriquecer o corpus do qual ela pretende tratar, mas que ela amplia e do qual passa doravante a fazer parte. ${ }^{80}$

À pergunta "Por que insistir aqui na espectralidade? Por que Yerushalmi ousou dirigir a palavra ao fantasma de Freud? Por que teve a audácia de the pedir uma resposta confidencial cujo arquivo ele não desvelará nunca?". $\bigcirc$ autor de Mal de arquivo parece não temer uma conclusão peremptória: "principalmente, porque a estrutura do arquivo é espectral" ${ }^{81}$ Como falar com o fantasma de Santos Dumont tal como "aparição" no filme-mutoscópio de 1901 ? (Figura 6).

Caberia evocar aqui, ou até mesmo invocar, uma alegoria usada por Hannah Arendt (em 1968) a propósito de Benjamin e reusada por Didi-Huberman a propósito de Warburg. É a alegoria do pescador de pérolas, que parece apropriada às operações do cinema de reapropriação de arquivo, e especificamente apropriada ao trabalho ao redor do filme-mutoscópio de Santos Dumont. Mais do que pesquisador estilo detetive ou caçador de cabeças, Warburg foi "um pesquisador do tipo pescador de pérolas" ${ }^{82}$

Após o mergulho que the faz encontrar uma pérola, o pescador (satisfeito e iludido com o triunfo de seu troféu) fixa-a numa ficha catalográfica supostamente definitiva e guarda-a em vitrine, sem suspeitar que "para além do enigma, há um mistério de natureza totalmente diversa". Até que ele repara, por acaso, e muito tempo depois, que a pérola era o olho de seu pai morto. A alegoria seria "conforme a inesquecível profecia cantada por Ariel, em A tempestade (ato 1, cena 2), de Shakespeare. Eis a tradução de Carlos Alberto Nunes: "Teu pai está a cinco braças./ Dos ossos nasceu coral,/ dos olhos, pérolas baças./ Tudo nele é perenal;/ mas em algo peregrino/ transforma-o o mar de contínuo". 83 


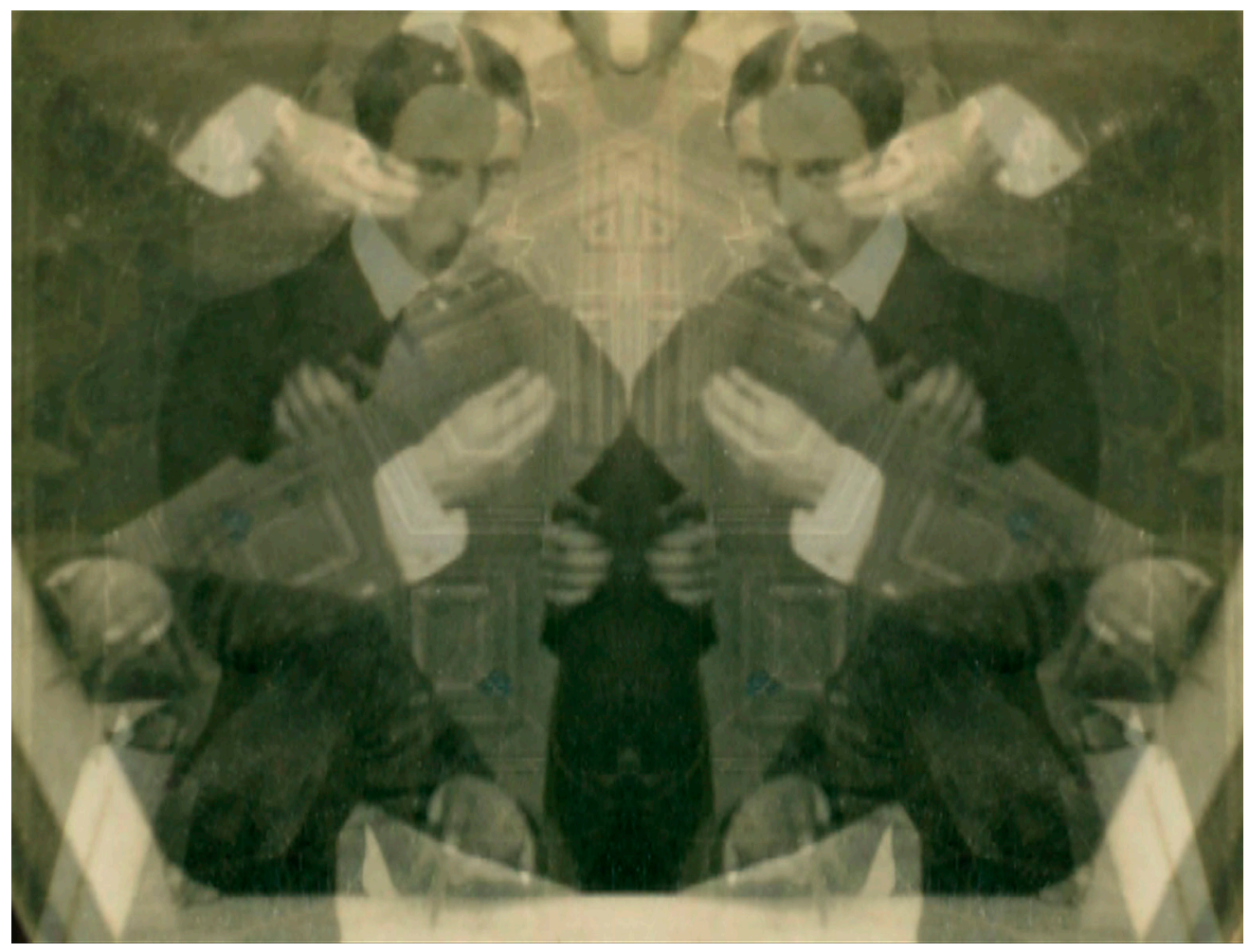

84. Didi-Huberman (2013, p. 425).

85. Didi-Huberman. Loc. cit.

Figura 6 - Fotograma de Santoscópio = Dumontagem, filme 35mm, 2010. Fonte: Coleção particular Cortesia: Carlos Adriano.

Obcecado, o pescador é impelido a um novo mergulho, e compreende

que os tesouros do mar proliferam, existem em número infinito. Não só seu pai afogado deixou-the outras maravilhas além da pérola singular do começo, tais como o coral de seus ossos e inúmeros outros detalhes, transformados em "tesouros insólitos", como há também, misturados ou dispersos, todos os corais e todas as pérolas de todas as gerações de ancestrais próximos ou distantes. Inúmeros pais jazem em inúmeros tesouros no fundo do mar. Coberta de algas e impurezas, já se vão séculos que essa herança espera para ser reconhecida, colhida, repensada. ${ }^{84}$

A reapropriação de um tempo e um tesouro perdidos ecoam a caverna do cinema infinito de Frampton que projeta e protege a colheita dos materiais de arquivo. Noutra fase do mergulho (nas águas da memória e da percepção), o pescador meta-historiador compreende

que aquilo em que ele mergulha não é o sentido, mas o tempo. Todos os seres dos tempos passados naufragaram. Tudo se corrompeu, com certeza, mas tudo ainda está lá, transformado em memória, ou seja, em algo que já não tem a mesma matéria nem a mesma significação. ${ }^{85}$ 
88. Nessa espécie de plágio, um escritor do presente apropria-se da obra (ou toma de empréstimo temas e motivos) de um escritor do futuro (e não de um escritor do passado, como no plágio clássico).

89. Bayard (2009, p. 154).

90. Bayard (2009, p. 100)

91. Xavier (2012, p. 457).

92. Do filme $O$ anjo nasceu (Julio Bressane, 1969). O cineminha do parque de diversões é anunciado por uma placa que assim o identifica: "cinematographo".
Insígnio insight, arregimenta a convocação sedutora, intimação coercitiva e cognitiva, que tanto evoca a loucura do mallarmaico Igitur ou a loucura ĺcaro de Santos Dumont:

No momento em que compreende isso, o pescador de pérolas sente um desejo imperioso: permanecer lá para sempre, fazer do meio orgânico em que ele nada - não do sentido dos próprios tesouros, mas da Leben dos fluxos que os possibilitaram - o objeto de sua busca. Ele bem sabe da loucura trazida por esse desejo: para conhecer completamente esse meio vital, esse meio de sobrevivência, seria preciso viver nele, afogar-se, perder a vida. ${ }^{86}$

Na experiência da criação artística não são convocados apenas os "fantasmas do passado" "mas tanto quanto, e talvez até mais, aqueles do futuro". ${ }^{87}$ No fascinante estudo de Bayard sobre o "plágio por antecipação", 88 o autor le psicanalista) descreve o revenant como o "escritor do passado com o qual um escritor [no presente] dialoga" e o survenant como o "escritor do futuro com o qual um escritor [no presente] dialoga". 89

A questão amplia-se para além da ordem da influência. Pois se fomos engendrados pelos autores anteriores (revenants) e assim temos um débito com eles, por conta de uma certa maneira de existirmos, ao mesmo tempo eles também têm alguma dívida conosco, "pelo suplemento de vida que damos a eles". O mesmo se daria com os autores posteriores (survenants), "pois é de sua obra futura - ao menos a título de possibilidade imaginária - que se nutriria nossa criação"; eles também "têm necessidade de nós para viver", por conta do modo como "acolhemos em nós a possibilidade que podem esperar para terem um caminho rumo à existência e serem plenamente reconhecidos". ${ }^{90}$

Em 1945, Celestino Silveira deparou-se com um fantasma e com um fóssil. Ele até poderia fazer uso desta citação em sua reportagem na Revista da Semana, referindo o barroco à origem do drama de Santos Dumont:

Tudo começa, em Benjamin, com uma teoria sobre o barroco, reflexão que mergulha fundo na compreensão de uma arte correlata a uma aguda consciência de crise e envolta nos labirintos do mundo da danação terrestre: o homem afogado no tempo, separado do mundo da graça (dimensão utópica de salvação). ${ }^{91}$

Em determinado trecho de sua análise da cena ${ }^{92}$ dos personagens num cineminha de parque de diversões - e o cinema, historicamente, começou de fato como arração de feira -, Ismail Xavier procede a uma formulação que se aplicaria a uma poética do found footage a partir das ilações feitas por Celestino Silveira sobre a peça de Santos Dumont do Museu Paulista l"Sem dúvida, foi esse um dos pontos de referência 
para a descoberta do cinematógrafo"): "evocação da idade da inocência 'cinematographo' - cujo retorno sabe impossível, mas cuja referência se mostra fecunda na gestação de uma poética (sem passado, não haveria poesia)" (Figura 7). ${ }^{93}$

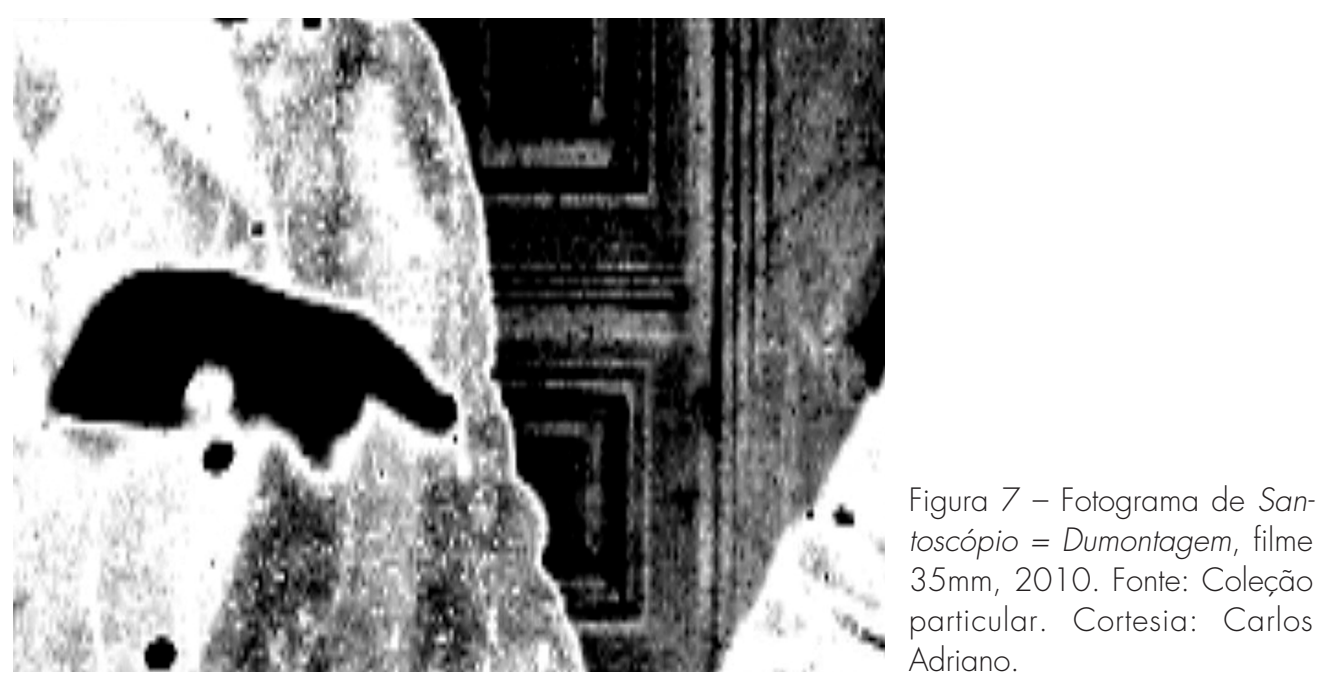

MÉTODO E POÉTICA

Para o cinema de reapropriação found footage, "sem passado, não haveria poesia". Codificado como um "gênero" cinematográfico ou um "procedimento" técnico de fazer filmes, o found footage pode também ser tomado como método e como poética. Por trabalhar justamente o mundo como arquivo de informações e como contínuo processo de mediação da matéria de base, o found footage apresenta-se sob a forma de um procedimento metodológico apropriado para entender a imagem nos campos de estudo dos meios audiovisuais.

A partir de um corpus-assemblage de noções como meta-história (Frampton), alegoria das ruínas (Benjamin), sobrevivência das imagens através dos tempos (Warburg) e da nova história do cinema das origens (early cinema), levanta-se a hipótese de que o found footage possa ser um método poético de organização e tratamento da informação audiovisual a partir das dobras e das sobras da história.

A arte do cinema é algo como o depositário de um passado - o patrimônio de uma memória, em que a pátina do tempo vai depondo pó e depositando seus espectros. $\bigcirc$ cinema é como um repositório - assim como um museu, um arquivo e um livro, que guardam a memória do mundo. O cinema é fonte de preservação 
94. Bayard (2009).

95. Aqui "menor" e "maior" não implicam "hierarquização de autores" nem comparação entre eles; "mas simplesmente a importância da forma ou do tema em jogo para cada um deles, para um e para o outro" (Bayard, 2009, p. 45).

96. Bayard (2009, p. 42).

97. Bayard (2009, p. 47).

98. Bayard (2009, p. 21).

99. Bayard (2009, p. 38). e difusão de uma memória, coletiva ou individual. Portanto, é portador de informação e conhecimento. Para o cinema experimental, do qual se origina o found footage, o conhecimento se dá pela própria estrutura, pela nova forma de linguagem que o filme instaura.

Como um método crítico, o cinema de reapropriação de arquivo é pertinente à configuração, às contingências e às exigências do mundo presente. Crítico como um termo aplicado ao ofício e ao exercício da crítica, mas também como um termo que define uma posição de espanto e até uma situação de crise, diante de um mundo também em crise, que desafia tanto nossa sobrevivência como nossa compreensão.

C cinema found footage define-se em função da montagem. A montagem (também chamada de edição) é aquele expediente da linguagem cinematográfica em que a ação de cortar tem duplo sentido (simultâneo e paradoxal): de separar para juntar. Ao cortar uma imagem em movimento, decidem-se os instantes em que ela começa e acaba (separa-se um trecho escolhido de um conjunto contínuo), o momento em que uma imagem vai se juntar à outra, o modo como se faz a articulação de imagens.

A reapropriação, como a montagem de temporalidades no cinema de found footage, poderia guardar índices e indícios de remeter à noção de "plágio por antecipação", tal como sistematizada por Bayard. ${ }^{94}$

Assim, é possível dizer que Sófocles plagia Freud e Poe, que Fra Angelico plagia Pollock, que o Laurence Stern de Tristram Shandy é contemporâneo de Joyce, Virginia Woolf, Apollinaire, Mallarmé. E assim é possivel ler um texto "menor" de Maupassant (Fort comme la mort, publicado em 1889) como se fosse influenciado pelo texto "maior"95 de Proust (Á la recherche du temps perdu, 1913).96 Lê-se Maupassant através de (graças a) Proust; uma página de Maupassant, escrita antes de Proust, torna-se proustiana com (após) nossa leitura de Proust. ${ }^{97}$

A noção de "plágio por antecipação" origina-se do OuliPo /Ouvroir de Littérature Potentielle), grupo liderado por Raymond Queneau e François Le Lionnais, do qual fizeram parte Georges Perec e Italo Calvino. ${ }^{98}$ Quatro são os critérios para essa espécie singular de empréstimo entre obras: semelhança, dissimulação, inversão temporal, dissonância. ${ }^{99}$ Para haver "plágio por antecipação" deve haver semelhança dissimulada entre as obras, inversão temporal lo que vem antes e depois) e é preciso que a obra plagiadora seja dissonante em relação ao conjunto da obra desse autor ou de seu tempo.

Sob a égide de Borges, que "mostra como cada escritor inventa seus precursores a fim de facilitar seu trabalho de criação", dá-se "a influência 
retrospectiva"100 que baseia o "plágio por antecipação". Em seu estudo de caso (o já referido "Kafka e seus precursores), 101 e peça de resistência dessa "teoria" que, de resto, encontra-se formulada ficcional, coerente e dispersamente por praticamente toda sua obra -, Borges monta uma "coleção heteróclita" de sete textos que atestam a influência retroativa do escritor tcheco sobre escritores anteriores a ele. ${ }^{102}$ Ou como uma parábola de Kierkegaard, um apólogo chinês de Han Yu ou um poema de Browning "plagiaram por antecipação" Kafka, ou ainda como estes (e os outros quatro textos) não existiriam se não fosse (nossa leitura de) Kafka.

É a noção borgeana de que não há uma essência imanente dos textos nem dos gêneros; sua definição de literatura: afinal, os livros são diferentes uns dos outros não pelo modo como são escritos, mas pelo modo como são lidos. Em conferência sobre o gênero policial em 1977, ele escreveu: "Os gêneros literários dependem, talvez, menos dos textos que do modo como os textos são lidos". ${ }^{03}$ Em Nota sobre (para) Bernard Shaw (1951), Borges parece plagiar o OuliPo:

Uma literatura difere de outra, ulterior ou anterior, menos pelo texto do que pela maneira de ser lida: se me fosse outorgado ler qualquer página atual - esta, por exemplo - como a lerão no ano 2000, eu saberia como será a literatura do ano 2000.104

São ideias que deslocam a importância do autor para o domínio do leitor e que ganhariam corpo nos revoltos anos 1960 com, por exemplo, a ideia sobre "a morte do autor". ${ }^{105}$

Ao remeter à ordem das filiações anteriores e esclarecer as filiações por virem, demarcando a "influência retrospectiva", chega-se a um chamado, que pleiteia "por uma história literária de antecipação"106 e, por consequência e extensão, uma "crítica de antecipação"107. Ou seja, o estudo sobre a criação artística (baseada no "plágio por antecipação") termina por originar tanto uma história como uma crítica de antecipação.

Para tratar de objetos que assumem a preocupação central de uma historiografia pós-moderna - "o reconhecimento de que há eventos históricos que, por sua natureza, desafiam a representabilidade"108 - há uma senha: recorrer ao historiógrafo e narratologista Hayden White, que privilegia o discurso narrativo como método de entender a história - "a historiografia como o estudo de uma série de problemas formais de narrativa e enredamento que são mais de uma natureza literária do que científica" 109 No ensaio "O evento modernista", 110 Hayden White teoriza as mudanças artísticas na representação da história contemporânea, baseado na magnitude e complexidade dos eventos do século XX: "tais experiências convulsivas são difíceis de descrever e impossíveis de explicar por meio de modos tradicionais de narração e enredo". 111
100. Bayard (2009, p. 61).

101. Borges (2007)

102. Bayard (2009, p. 65).

103. Borges (2011, p. 52).

104. Borges (2011, p. 183).

105. Barthes (2004, p. $57-$ 64).

106. Bayard (2009, p. 133).

107. Bayard (2009, p. 153).

108. Skoller (2005, p. xvi).

109. Skoller (2005, p. xxii).

110. Ensaio publicado em Figural Realism: Studies in the Mimesis Effect (WHITE, 2000). White é autor do livro Metahistory: the historical imagination in nineteenth-century Europe, publicado em 1973. Em seu artigo sobre a meta-história, publicado originalmente em 1971, Frampton não poderia mencionar essa fonte (ou poderia, se tivesse tomado contato com o estudo ou a nomenclatura de White antes da publicação em livro?). Republicado por Frampton em 1983 no livro Circles of confusion, White não é referido. Neste artigo, uso "meta-história" apenas nos termos do cineasta.

111. Skoller (2005, p. xxxvi). 
112. Apud Skoller. Loc. cit.

113. Skoller. Loc. cit.

114. Skoller. Loc. cit.

115. Bayard (2009, p. 66).

116. Bayard (2009, p. 93).

117. Bayard (2009, p. 96).

118. Bayard (2009, p. 98).

119. Bayard (2009, p. 105).
White julga que "a magnitude de tais ocorrências a impossibilita, para qualquer relato objetivo ou explanação racional baseados apenas sobre os fatos, de ser suficiente para representar sua complexidade". ${ }^{112}$ Esses eventos são tão amplos e de difícil manejo que "na verdade começam a desafiar uma explicação, resistir à representação, e recusam o consenso sobre suas significações ou mesmo sobre o que aconteceu". ${ }^{113}$ Para White, "o evento modernista borra as sólidas distinções entre pressupostos fundadores do realismo ocidental, especialmente a oposição entre fato e ficção". ${ }^{114}$

Em suas ficcionalizações conceituais, a pedagogia crítica da meta-história de Frampton encontra pontos de coincidência com a "história literária de antecipação":

Um grande escritor não se contenta em interferir nos predecessores que se revelem ter the influenciado. Ele modifica também, ao thes perturbar por sua lógica singular, o conjunto das linhas de força da história literária anterior, que apareciam assim, por esse jogo de reconstrução imaginária que é toda leitura viva, como que devendo conduzir irresistivelmente à sua presença. ${ }^{115}$

Em sua conferência no Collège de France sobre o ensino da poética, Paul Valéry propõe outra história literária, uma história do espírito da literatura, que produz ou consome literatura, sem os fatos episódicos de circunstância, sem até citar os nomes de autores. ${ }^{116}$ História que também guardaria pontos de coincidência com a meta-história de alusões idealizada por Frampton. Por meio da poética do found footage, no "cinema infinito" já estariam contidos todos os fotogramas filmados, como a biblioteca virtual borgeana que formulava uma booleana de todas obras já escritas ou a serem escritas.

Para Valéry, estaria em pauta "a representação de uma literatura [...] segundo uma ordem [...] possível de ser bem diferente daquela que se fez - todas as combinações possíveis de linguagem". 17 Para Frampton, um cinema que poderia ter sido mas não foi.

Se "o grande escritor é aquele que dispõe de um acesso privilegiado à combinatória geral da linguagem", 118 a mesma assertiva poderia ser dita sobre o cineasta de found footage que se orienta pela meta-história do arquivo do "cinema infinito". Ao constatar "que os escritores não se inspiram apenas naqueles que os precedem, mas igualmente naqueles que ainda vão sucedê-los", impõe-se a questão de uma "representação da história literária", "uma história literária autônoma" na qual "o conjunto da história literária que se resolva a reescrever aceita levar em conta a noção de plágio por antecipação". 119

Partindo de uma "cronologia plural" que usa "sistemas de datação diferentes para os acontecimentos históricos de uma parte, e de outra parte para os 
acontecimentos literários ou artísticos", 120 conclui-se que "a história literária ou artística dispõe de uma cronologia autônoma, distinta daquela da 'história dos eventos'", 121 que tem pontos comuns com a meta-história de Frampton em sua articulação com o "cinema infinito" operado pelo found footage.

Em seu depoimento para o filme Santos Dumont: pré-cineasta?, Ismail Xavier aponta outros padrões para trabalhar com esse grande arquivo que não seja "um padrão histórico no sentido mais clássico, como faz o filme de compilação": um padrão como o do found footage - "de caráter mais ensaístico, pautado na ideia de que é uma meditação sobre aquele material de arquivo" reapropriado e manipulado - "tem a ver com uma intertexualidade, com um diálogo entre programas poéticos". ${ }^{122}$

A seguinte noção encontra ressonância na tradição de invenção de percursores imaginada pela meta-história e aplicada ao found footage: "toda nova obra - e, mais ainda, toda obra de importância - desloca o conjunto da cronologia constituída", assim reivindica uma "mobilidade da nova história literária". ${ }^{23}$ É "a organização transitória do campo literário, determinada pelo jogo complexo e anacrônico de influências". ${ }^{124} \bigcirc$ cinema de reapropriação é anacrônico em sua constituição e operação: "o anacronismo em história consiste em reconstituir o passado através de categorias mentais do tempo presente". ${ }^{125}$

Por sua montagem de atrações e ressonâncias, o cinema de found footage carrega tempos e temporalidades distintas no interior de uma mesma imagem. Aqui poderia ser apropriada a exortação sobre "a necessidade do anacronismo", reapropriando-se da formulação: "uma extraordinária montagem de tempos heterogêneos formando anacronismos". ${ }^{126}$

Em seu depoimento para o mesmo filme, ${ }^{127}$ Solange Ferraz de Lima, curadora-docente do Museu Paulista e sua atual diretora, comenta o "gênio inventivo" de Santos Dumont, que combinava folha de flandres, bambu e restos de relógio, referencial a um "conceito anacrônico de sucata", para o processo de criação de seus inventos.

A ideia de um pensamento selvagem de bricolagem, extraída de LéviStrauss, ${ }^{128}$ pode ser apropriada como mote de procedimentos de vanguarda. Evidente é o caráter de desconstrução do mito - e, no caso das vanguardas e de Santos Dumont, a máquina é um mito -, do prazer lúdico de descobrir as interconexões das materialidades como índices de uma mentalidade.

A bricolagem é congenial ao cinema de reapropriação não apenas pela coincidência dos aspectos mais visíveis da manipulação de um objeto lou de fragmentos de objetos) pelas mãos e da composição de um novo objeto a partir de partes provindas de outro(s). A translação de temporalidades (por vezes distantes; por vezes incompatíveis segundo uma concatenação cronológical que estão naturalmente cravadas nos
120. Bayard (2009, p. 153).

121. Bayard (2009, p. 109).

122. Santos Dumont: pré-cineasta? (2007-2010),

123. Bayard (2009, p. 118).

124. Bayard (2009, p. 119).

125. Bayard (2009, p. 125). Sobre o elogio do anacronismo na história, cf. Loraux (1993), e sobre o conceito de anacronismo na verdade do historiador, cf. Rancière (1996).

126. Didi-Huberman apud Bayard (2009, p. 127, grifos do original).

127. Santos Dumont: pré-cineasta? aborda aspectos históricos e artísticos dos primórdios do cinema (early cinema, cinema de atrações) e do cinema de reapropriação de arquivo (found footage, filme de reciclagem), por meio de documentos, metáforas visuais e da articulação própria de um ensaio poético. Contém entrevistas com os especialistas: Charles Silver, Eduardo Morettin, Henrique Lins de Barros, Ismail Xavier, Ken Jacobs, Laurent Mannoni, Nicole Brenez, Paul Spehr, Ron Magliozzi, Solange Ferraz de Lima.

128. Lévi-Strauss (1997). 
129. Wykeham (1966, p. 284). materiais é um elemento decisivo: o deslocamento dos tempos de cada pedaço material e sua conjugação num terceiro tempo demarca a confecção de um artefato compósito. É a estrutura mesma de pensamento e de imaginação envolvida nos processos de bricolagem e de reapropriação que os aproxima.

Algumas imagens podem ser justapostas ao redor do signo Santos Dumont bricoleur, que reúne manufatura e dispositivos anteriores outros para fabricar suas invenções - o primeiro filme-teste de Marey: filmagem de sua mão (1 889); o primeiro filme-teste de Dickson: ele e William Heise apertando as mãos (1 892); a primeira chapa de raio x: mão da mulher do inventor Wilhelm Conrad Röntgen (1895); a manivela no começo do cinema: manipulação do cinegrafista-projecionista (variando velocidades de filmagem e de projeção); a manipulação do espectador no mutoscópio (Figura 8).

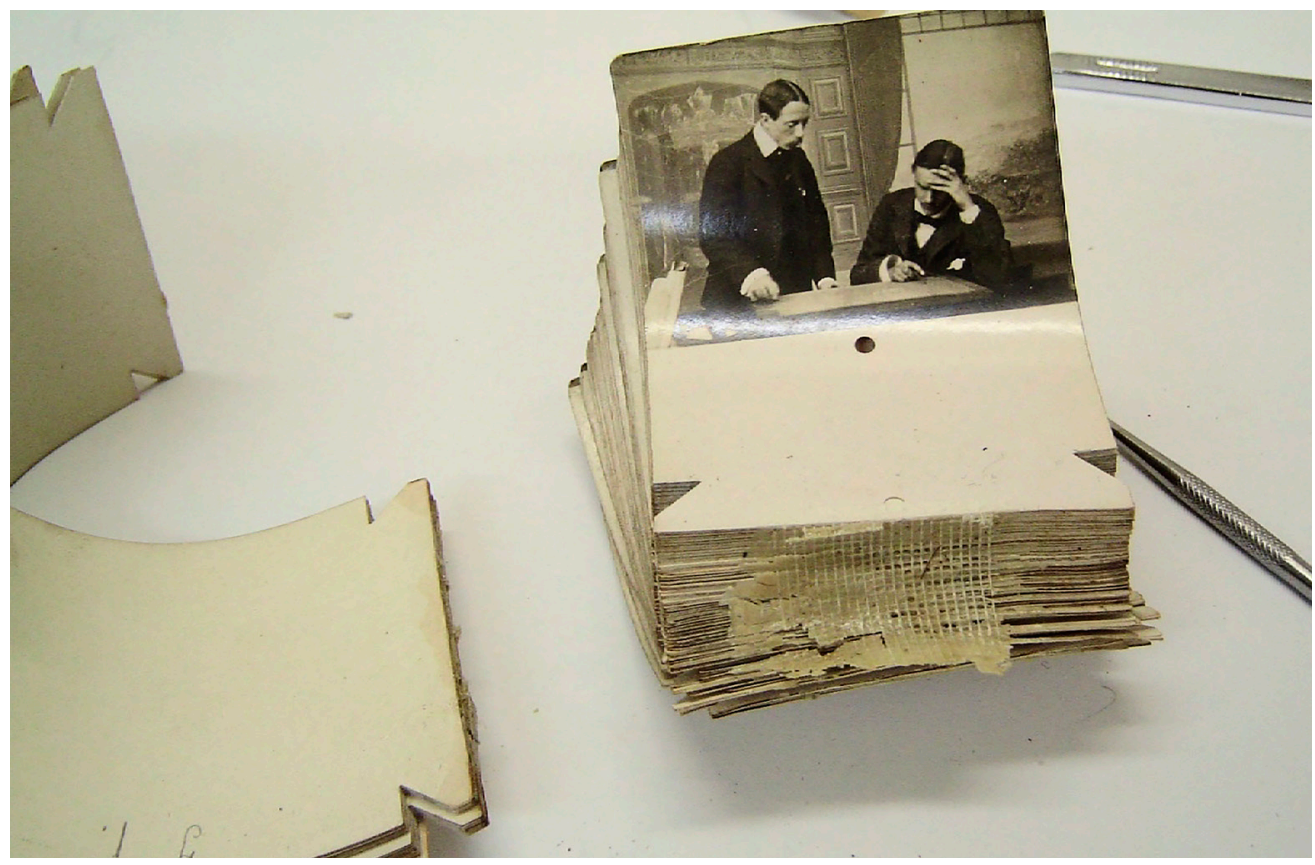

Figura 8 - Cartões do mutoscópio. Fonte: Acervo do Museu Paulista da Universidade de São Paulo. Foto: Carlos Adriano.

Um fato biográfico pode ser lido quase como uma alegoria de um processo pós-operatório de todos seus protocolos de invenção. Apesar do juízo paradoxal: "Ele era um projetista errático, mas um maravilhoso artesão". 129 Após ter se dedicado com tanto esforço à manipulação mecânica de peças e engrenagens, no intuito terapêutico Santos Dumont passou a se dedicar à encadernação em 1927, na Suíça; o livro Botticelli, de Adolfo Venturi, foi um de seus primeiros trabalhos nessa área. Dois fechos de metal dourado promovem um curto-circuito nas curvas fechadas das letras " $S$ " e "D". 
Objetos da Coleção Santos Dumont do Museu Paulista denotam o índice háptico: chassis com filmes velados; chassis para filmes; "alphabeto Braille" ("signal de número", Instituto Benjamin Constant, Praia da Saudade, Rio de Janeiro, 1903); os desenhos (projetos de balões e aeronaves com estilo gráfico minimal) revelam o traço de sua mão; o documento em papel craft, com desenho a lápis de uma circunferência dividida em doze partes, junto com manchas de cola e marcas de dobras, riscos e garatujas, aproximando Dumont de Duchamp la tela de celibatários e garatujas do acaso em $\bigcirc$ grande vidrol - na roda das articulações, lembre-se que um dos Rotoreliefs (1935) de Marcel Duchamp porta o título Montgolfier, em homenagem aos criadores de balões que tanto encantaram Santos Dumont; seguindo o nome, a obra de Duchamp apresenta em espirais rotatórias o esquema gráfico de um balão.

Os esboços que Santos Dumont traçou de seus dirigíveis têm uma qualidade gráfica que prima pela economia e elegância de linhas, de talhe moderno, com uma espécie de design digno da austera Bauhaus lem que pese o exagero de propósitos na conexão). A operação com materiais era inerente à transformação de mentalidades: "a princípio tinha-se que lutar não só contra os elementos, mas também contra os preconceitos". ${ }^{130}$

New York Mail Express (19 de abril de 1902) publicou um artigo de certa afetação, que prometia mostrar um lado pouco conhecido de Santos Dumont, ao descrever a suíte de três quartos que dava vista para os Champs Elysées e devassar até o quarto de dormir todo em azul e branco. A reportagem "Santos Dumont tricota e costura" informa que "ele devota seu tempo livre ao bordado, ao tricô, e mesmo à difícil façanha da tapeçaria", "mas é no trabalho de tricô que Santos Dumont é mais viciado". A decoração transborda para a oficina: "inúmeras mesas são feitas de pretexto para uma variedade infinita de bricabraque, que é disposta sobre elas com estudada confusão". Antes de concluir a nota falando de uma suposta tórrida paixão de Santos Dumont por Edna Powers, uma americana em Paris, o leitor fica sabendo que "tudo no quarto é do melhor bom gosto, e nada nele indicaria por um momento um toque masculino". Seria pertinente trançar outro aspecto da bricolagem nos fios de tecido literais da tessitura, percebendo uma analogia que remeteria ao princípio de tecelagem vislumbrado por Benjamin na origem da trama narrativa?

Uma de suas ideias aéreas acalentava a insistência numa profissão de fé: "há um ditado que ensina 'o gênio é uma grande paciência' [...]. As invenções são, sobretudo, o resultado de um trabalho teimoso, em que não deve haver lugar para o esmorecimento". ${ }^{131} \mathrm{Na}$ edição do autor de $\bigcirc$ que eu vi o que nós veremos, livro dividido em duas partes seguindo a secção dos tempos verbais do testemunho e do prognóstico, escrito em sua casa, A Encantada, no Morro do Encanto, em Petrópolis, ele fez imprimir na capa: "Santos=Dumont / inventor".
130. Santos Dumont (1918, p. 9). Os esboços de Leonardo Da Vinci sobre dispositivos para o voo humano, com seu design de asas e estruturas, permitem, por sua vez, conexões diretas com um método de pensamento "heurístico-semiótico", "quase-método", tal como elaborado por Paul Valéry (PIGNATARI, 1979, p. 13-20).

131. Santos Dumont (1918, p. 43). 
132. Em seu depoimento para Santos Dumont: pré-cineasta? (2007-2010), Nicole Brenez manifesta-se sobre o que ela chama de "artistas historicamente responsáveis", que zelam pela perenidade e renovação de seu meio (no caso, o cinema) justamente por terem consciência dos processos e das formas de mutação e de hibridização de suportes e de materiais.
"Ce que je ferai ce que l'on fera" é o intertítulo de uma reportagem publicada na revista que porta justamente o nome Je Sais Tout (15 de fevereiro de 1905). Comentando o dispositivo de um dos inventos de Santos Dumont, apropriadamente matava a charada heurística do cientista-bricoleur: "uma descoberta muito simples e muito engenhosa, mas... era necessário encontrá-la" 132 (Figura 9).

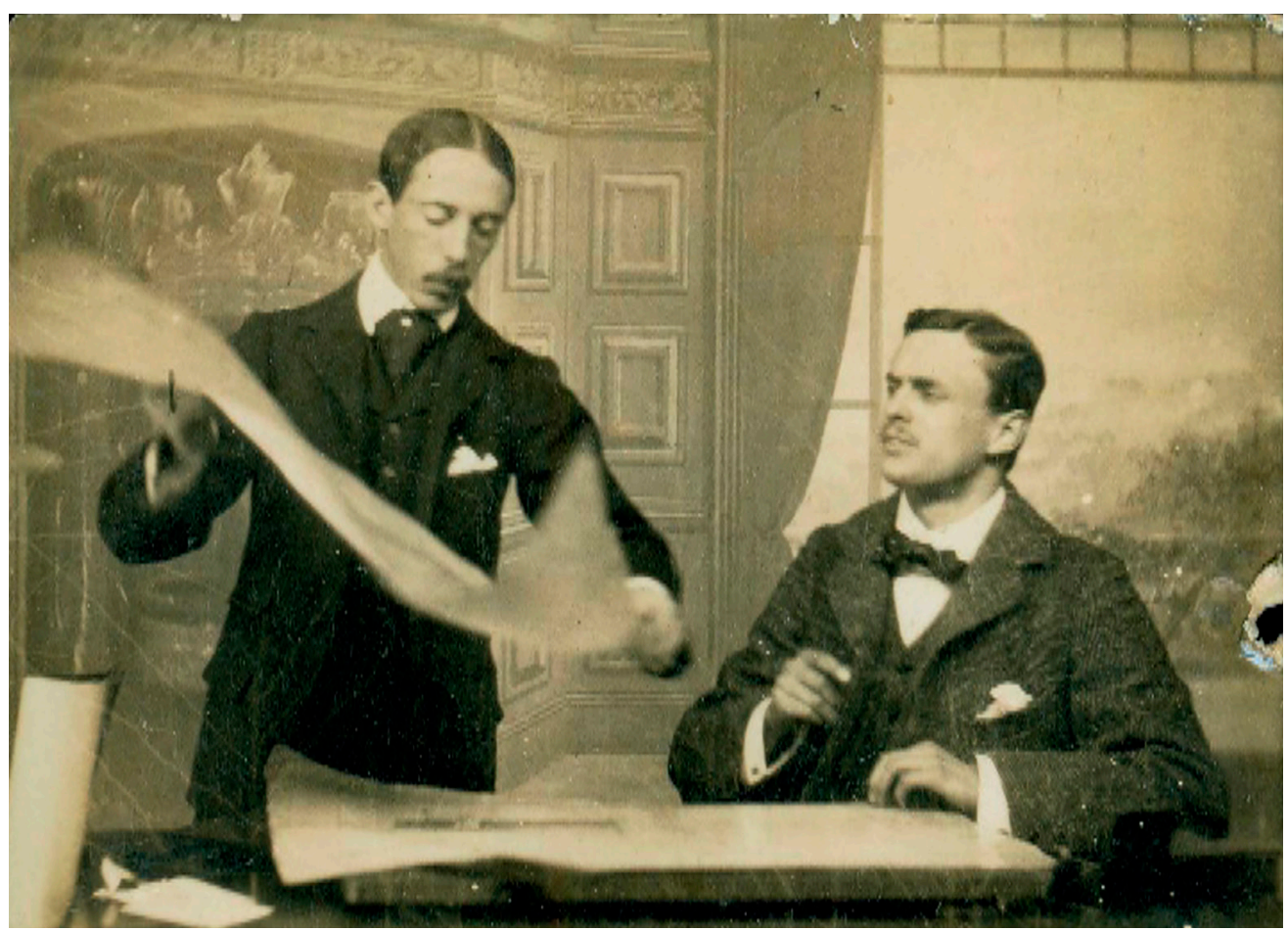

Figura 9 - Fotografia de Santos Dumont explaining his air ship to the Hon. C. S. Rolls, mutoscópio, 1901 . Fonte: Acervo do Museu Paulista da Universidade de São Paulo.

Uma hipótese pouco provável porém mais fascinante seria que Santos Dumont, em outro de seus ímpetos de bricolagem, teria manipulado o rolo de imagens do mutoscópio - talvez numa tentativa de conhecer a mecânica do dispositivo ou de articular outra montagem? -, colocando seu filme num carretel qualquer que the caiu às mãos. Isso porque há uma numeração inscrita no carretel de mutoscópio do Museu Paulista que apontaria um outro filme que não o de Santos Dumont, registrado como n 980 no catálogo de produção da American Mutoscope \& Biograph Co. lantes chamada American Mutoscope Co. e depois Biograph Co.l

O microfilme Motion picture catalogs, editado por Charles Musser, reproduz os catálogos que sobreviveram. $\bigcirc$ assunto indexado sob $n^{\circ} 980$ era um estaleiro filmado na Filadélfia em 1899 (Cramp's shipyard), o que até está de algum modo 
afinado (também na rima de "ship") a Santos Dumont, que construiria as primeiras instalações de um hangar no mundo em 1900 (ano seguinte à filmagem do estaleiro), em Saint Cloud, no Parque de Aerostação do Aeroclube francês lem 1903 ele terminaria um novo hangar, próximo à Porte de Bagatelle, em Paris).

Portanto, o carretel de mutoscópio encontrado em São Paulo poderia ser o de Cramp's shipyard e não de Santos Dumont explaining. Permanece intrigante a hipótese de que a série de cartões do filme de Santos Dumont foi acomodada num outro carretel de mutoscópio que não era o original.

Foi possível detectar saltos e discrepâncias na ordem de numeração dos cartões fotográficos do carretel do Museu Paulista, corrigidos quando foi feita a reconstituição/restauração do filme para manter o movimento contínuo. Os cortes aos saltos têm uma qualidade áspera. Um exame livre de preconceito lo padrão de corte do cinema clássico) permite especular se Santos Dumont teria interferido na disposição dessa secção de fotos desordenadas, e apostar no princípio do erro como elemento criativo, contribuição múltipla dos equívocos da desmontagem.

A hipótese de bricolagem ocorre porque há nesse carretel do mutoscópio uma sequência de cartões fotográficos fora de ordem. Como se enredado no loop de um pesquisador-Sísifo, o encanto da revelação extraordinária choca-se com a constatação decepcionante do banal, se supusermos que o carretel simplesmente se quebrou, em alguma exibição ou durante os movimentos de sua existência. $\bigcirc$ desarranjo daquela sequência, com as imagens fora da ordem em bruscos saltos de movimento e em quebras de descontinuidade, poderia sugerir o desajeito de algum reparo displicente e descuidado ou uma outra forma de articulação, um pensamento primitivo de montagem, de alguém inocente de cinema, tateando na aventura de um novo meio.

Na tradição das vanguardas, que propõem novos modelos de expressão (para o artista) e de apreciação (para o espectador) e assim formulam seu próprio campo demarcatório (por inaugurarem justamente um novo território), sugerem a exigência de outros parâmetros críticos, ou seja, a proposição de um método adequado ao seu objeto e irredutível a certas generalizações. Por atuar sobre uma memória histórica de um meio (no caso, o cinema) e por promover uma nova forma de mediação entre a obra de arte (no caso, o filme) e o espectador, o found footage abre um novo campo de atuação e reflexão para a pesquisa. Por operar nas fronteiras entre disciplinas, o found footage conjugaria métodos e formulações de uma pesquisa. Um objeto (filme) sugere um método (found footage).

Assim, "a influência do porvir" afeta não apenas a escritura de novas obras - quando os autores se apropriam de temas e motivos posteriores -, mas também afeta a pesquisa e o ensino ${ }^{133}$ que se veem diante da tarefa de reescrever outra história (ou meta-história) da literatura ou da arte, mais afinada a noções vivas e 
134. Santos Dumont: pré-cineasta? (2007-2010).

135. A existência de uma série de dispositivos estereoscópicos (que não retratam aeronaves de Santos Dumont) na Coleção do inventor no Museu Paulista poderia ser explicada, ou ao menos imaginada, pela prática de palestras ilustradas. móveis. Noël Carroll avaliou a meta-história de Frampton como expediente de manutenção e continuidade de seu trabalho criativo, a sobrevivência da imagem de artista e a consistência ressonante de sua arte.

Se a denominação found footage compreende primordialmente o campo da prática da produção de um filme, poderíamos entender que essa terminologia também abarcaria o campo da teoria crítica de um método. Para realizar um filme de reapropriação, o cineasta mobiliza não apenas sua perícia artística e técnica, mas ainda sua expertise crítica e teórica. Para escolher e editar imagens filmadas por outros, em outros tempos e outros espaços, o cineasta agencia seu repertório de informações culturais e sua sensibilidade no acesso aos arquivos.

Para retrabalhar as imagens por meio de manipulações (texturas), o artista precisa mergulhar em seu repositório de conhecimentos sobre arte, história, ciência. A reapropriação de arquivo demanda dos que nela se aventuram o movimento de dotar de novo sentido um material escavado de um arquivo carregado de sentidos originais e por vezes perdidos, para reimaginar uma memória. A reapropriação do conhecimento nos campos da arte ou da crítica, com referências creditadas ou não, são configurações possíveis de um método found footage. Em seu depoimento para o filme Santos Dumont: précineasta?, Ismail Xavier comenta:

O found footage é capaz de gerar relações, introduzindo descontinuidades, interrupções, retornos - essa outra temporalidade, quando se intervém no material, cria-se uma experiência extremamente reveladora e que tem uma força de conhecimento. ${ }^{134}$

Baseado na tradição que mescla difusão da ciência e diversão ilusionista, podemos imaginar - a partir do filme-mutoscópio explicando seu dispositivo Santos Dumont como um showman, entre o lecturer de lanterna mágica que dirige (diverte, ensina) o espectador e o cientista que mostra a anatomia de inventos. ${ }^{135}$ A indução é fascinante, mesmo que desautorizada pelo próprio. $\bigcirc$ New York Journal (1 de maio de 1902), em artigo de curioso título, "Santos Dumont in flight, but not on air ship", anuncia em intertítulo que a máquina $n^{\circ} 6$ do inventor será exibida perto de Coney Island naquela temporada. Perguntado se planejava fazer exibições perto do célebre e popular parque de diversões e arrações baratas, ele foi enfático: não apareceria diante do público em seu dirigível, a menos que fosse para competir por um prêmio - "não sou um showman".

Elemento detectado no cinema das origens, que permite esse estudo histórico transversal, o papel do showman pode se confundir com o do lecturer. Esses tributários das apresentações de lanterna mágica e outros espetáculos ópticos eram responsáveis por mediar a relação do espectador com o filme, suprindo-o de 
suplementos informativos: podiam explicar uma narrativa obscura (seja pela falta de elos narrativos numa sintaxe ainda desconexa, seja pela confiança do produtor no aspecto "conhecimento prévio" do público, quando adaptava uma canção ou conto de suposto domínio popular), podiam chamar a atenção para algum ponto despercebido no quadro (quando a tela estava saturada de elementos visuais que dispersavam o olhar), podiam fornecer comentários que expandiam o sentido da cena. Os primeiros exibidores-showman exerciam grande controle sobre as exibições que apresentavam, remontando os filmes que haviam comprado e fornecendo uma série de suplementos fora da tela, como efeitos sonoros e comentário falado. ${ }^{136}$ A presença desse animador, que oferece a atração diretamente ao espectador, define uma abordagem que está na formação do próprio cinema. ${ }^{137}$

O método da reapropriação de materiais de arquivo proposto pelo found footage possibilita a configuração de uma poética, justamente por instaurar uma ação material sobre um pensamento artístico e uma reflexão conceitual sobre um dado histórico (o objeto ou conjunto de objetos que são reapropriados). $\bigcirc$ mutoscópio explica a invenção do pensamento de Santos Dumont. Poética da bricolagem, poética da meta-história (Figura 10).

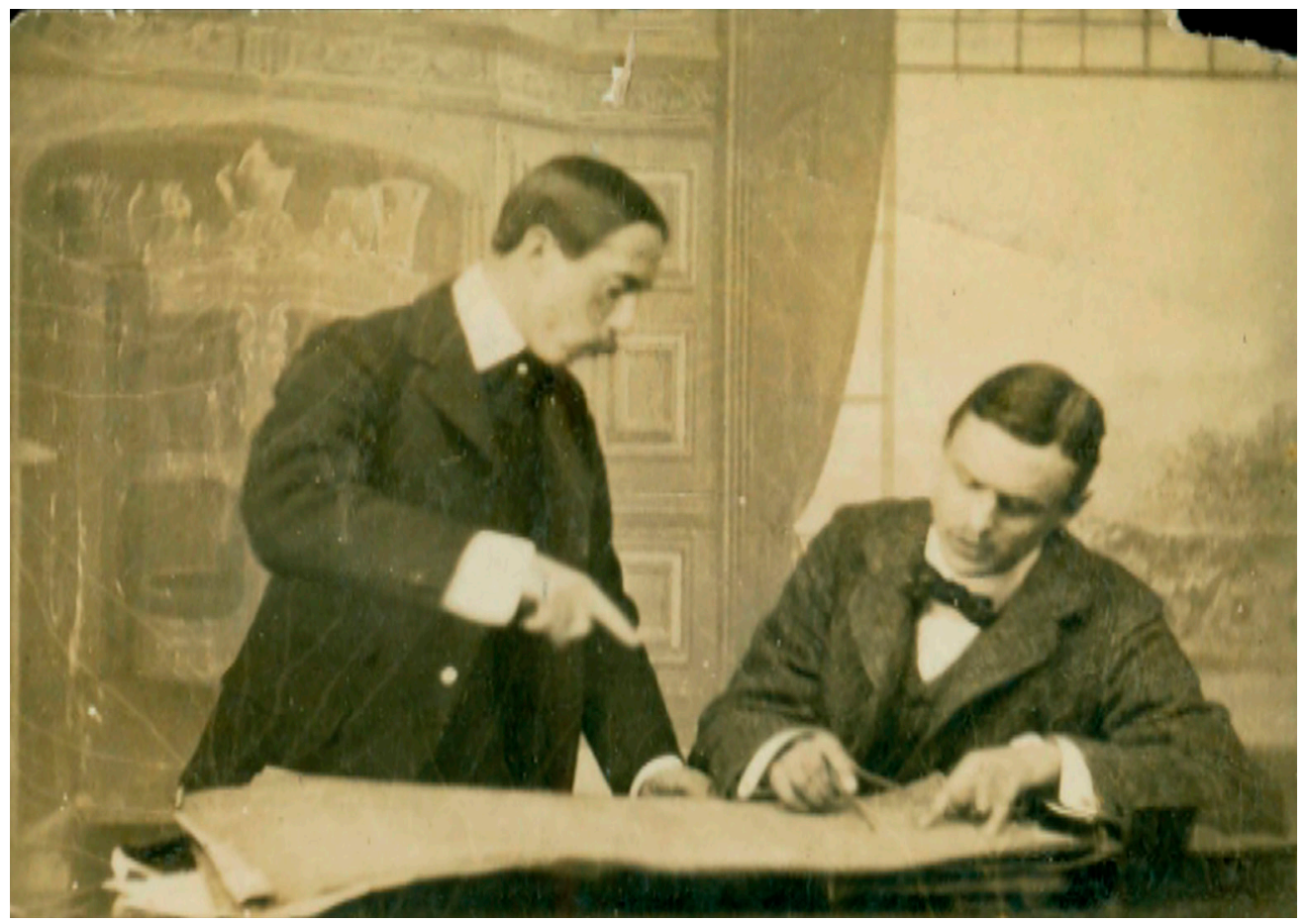

Figura 10 - Fotografia de Santos Dumont explaining his air ship to the Hon. C. S. Rolls, mutoscópio, 1901. Fonte: Acervo do Museu Paulista da Universidade de São Paulo.
136. Gunning (1990, p. 58). 137. Gunning (1990, p. 59). 
139. Beveridge (1980).

\section{CONSIDERAÇÕES FINAIS}

O cinema de reapropriação de arquivo guarda um (in)certo mistério. Nele, é possível fazer conviver a meta-história de Hollis Frampton, a alegoria das ruínas de Walter Benjamin, a imagem sobrevivente de Aby Warburg. Mas, para além do fascínio que exercem as imagens, provedoras de enigmas - e não é fortuito notar que "enigmas" é um anagrama de "imagens" -, ainda resta a indagação sobre como, quando e por quê as imagens se formam. E como se dá o processo de encontro, como as imagens chegam a nós, vindas de nosso inconsciente individual ou de um inconsciente coletivo (por meio dos arquivos, da memória institucionalizada).

Todo o itinerário de pesquisa ao redor da até então desconhecida peça do Museu Paulista reflete e repercute - até no figural de seus movimentos concêntricos e excêntricos, suas derivas e desvãos, e também no figural dos movimento dos voos de Santos Dumont - a possibilidade de um método e de uma poética da reapropriação de materiais de arquivo. Reflexão e ressonância que se consubstanciam ainda na produção de um filme de found footage e de um filmeensaio sobre found footage. Mesmo que todos os processos tenham sido produtos de esforços de construção (de descontrução e de reconstrução), é inegável a força de atração do acaso, do afortunado encontro.

A palavra serendipity foi criada pelo escritor britânico Horace Walpole, em carta datada de 28 de janeiro de 1754 e endereçada a Horace Mann, a partir do conto persa infantil Os três príncipes de Serendip. ${ }^{138} \mathrm{~A}$ história conta as aventuras dos príncipes do Sri Lanka (comerciantes árabes da antiguidade chamavam a terra de Serendib) que viviam fazendo descobertas inesperadas, cujos resultados eles não estavam procurando propriamente. Graças à sua capacidade de observação e sagacidade, eles descobriam "por acidente" a solução para dilemas impensados. Tal característica os tornava especiais, não apenas por terem um dom ou dote especial, mas por terem a mente aberta para múltiplas possibilidades.

Muitas descobertas científicas são feitas por acaso. Beveridge ${ }^{139}$ distingue três diferentes tipos de descobertas casuais: intuição a partir de justaposição de ideias, intuição do tipo eureka e serendipity. A descoberta do que não se espera, entre o acaso e a co-incidência, o afortunado encontro com o que não se imagina, entre a sorte e a abdução, devem ter participado do processo de invenção de várias peças de Santos Dumont. E certamente participaram do "achado" da peça do Museu Paulista.

Uma licença ou uma justiça poética? Muitas descobertas artísticas são feitas por acaso. E por poesia. 
Para além de seus generosos impulsos pedagógicos, um projeto poético do found footage - e seu projeto de método e poética - promove um encantamento, ou (des)contínuos reencantamentos, do mundo. Ao portar dados de documentos artísticos, ao propor um confronto com o conforto de repertórios apriorísticos, o cinema experimental redefinido pela reapropriação de arquivo comporta-se como um desafio à configuração do pensamento e de sua abordagem. $\bigcirc$ found footage é uma instauração do metacinema como meta-história. Logo, mesmo que demore, apesar de que perdure, tudo existe para acabar como found footage. 


\section{REFERÊNCIAS}

LIVROS, ARTIGOS E TESES

ADRIANO, Carlos (Org.). Dossiê Found Footage (I). Revista Laika, São Paulo, v. 3, n. 5, jun. 2015. (Org.). Dossiê Found Footage (II). Revista Laika, São Paulo, v. 3, n. 6, p. x-x, dez. 2015. . Re-Missões de Mário de Andrade: o rumor da imagem evasiva. Devires, Belo Horizonte, v. 12 , n. 2 , p. $12-37$, jul./dez. 2015.

BACHELARD, Gaston. A poética do espaço. São Paulo: Nova Cultural, 1988.

BARBER, Robert K.; Merton, Elinor. The travels and adventures of Serendipity: a study in sociological semantics and the sociology of science. New Jersey: Princeton University Press, 2006.

BARRY, Anthony. The kinora: motion pictures for the home, 1896-1914. London: The Projection Box, 1996.

BARTHES, Roland. O rumor da língua. São Paulo: Martins Fontes, 2004.

BAYARD, Pierre. Le plagiat par anticipation. Paris: Les Éditions de Minuit, 2009.

BENJAMIN, Walter. Origens do drama barroco alemão. São Paulo: Brasiliense, 1984. Passagens. Belo Horizonte: Editora UFMG; São Paulo: Imprensa Oficial do Estado, 2006.

BEVERIDGE, William Ian Beardmore. Seeds of discovey: a sequel to the art of scientific investigation. New York: Norton, 1980.

BORGES, Jorge Luis. Kafka e seus precursores. In: . Outras inquisições. São Paulo: Companhia das Letras, 2007. p. 121-130. 
BRENEZ, Nicole. L'étude visuelle: puissances d'une forme cinématographique: Al Razutis, Ken Jacobs, Brian de Palma. In: BRENEZ, Nicole (Org.). De la figure en général et du corps en particulier: l'invention figurative au cinéma. Paris: De Boeck Université, 1998. p. 313-335.

BRENEZ, Nicole; CHODOROV, Pip. Cartografia do found footage. Revista Laika, São Paulo, v. 3, n. 5, jun. 2015.

CAMPOS, Augusto de. Outro. São Paulo: Perspectiva, 2015.

CARROLL, Noël. A brief comment on Frampton's notion of metahistory. Millennium Film Journal, Nova York, n. 16-18, p. 200-205, fall/winter 1986-1987.

DERRIDA, Jacques. Mal de arquivo: uma impressão freudiana. Rio de Janeiro: Relume Dumará, 2001.

DIDI-HUBERMAN, Georges. A imagem sobrevivente: história da arte e tempo dos fantasmas segundo Aby Warburg. Rio de Janeiro: Contraponto, 2013.

ELSAESSER, Thomas (Org.). Early cinema: space frame narrative. London: British Film Institute, 1990.

GOMBRICH, Ernst Hans. Aby Warburg: une biographie intellectuelle. Paris: Klincksieck, 2015.

GUNNING, Tom. The cinema of attractions: early film, its spectator and the avant-garde. In: ELSAESSER, Thomas (Org.). Early cinema: space frame narrative. London: British Film Institute, 1990. p. 56-62.

Uma estética do espanto: o cinema das origens e o espectador (in)crédulo. Imagens, São Paulo, n. 5, p. 52-61, ago./dez. 1995.

JENKINS, Bruce (Ed.). On the camera arts and consecutive matters: the writings of Hollis Frampton. Cambridge, MA: MIT Press, 2009.

For a metahistory of film: commonplace notes and hypotheses". In: JENKINS, Bruce (Ed.). On the camera arts and consecutive matters: the writings of Hollis Frampton. Cambridge, MA: MIT Press, 2009. p. 131-139. 
LA FERLA, Jorge. Arrêt ton cinéma. In: CARLÓN, Mario; SCOLARI, Carlos A. (Orgs.). El fin de los medios massivos: el debate contínua. Buenos Aires: La Crujía, 2014. p. 135-159.

LAVENÈRE-WANDERLEY, Nelson Freire (Org.). Os recortes de jornais guardados por Alberto Santos Dumont. Rio de Janeiro: Instituto Histórico e Geográfico Brasileiro, 1972.

LÉVI-STRAUSS, claude. O pensamento selvagem. São Paulo: Papirus, 1997.

LEYDA, Jay. Films beget films: a study of the compilation film. NewYork: Hill and Wang, 1971.

LIANDRAT-GUIGUES, Suzanne; Gagnebin, Murielle (Orgs.). L'essai et le cinéma. Seyssel: Champ Vallon, 2004.

LORAUX, Nicole. Éloge de l'anachronisme en histoire. Le Genre humain, L'ancien et le nouveau, Paris, n. 27, 1993.

O filme-ensaio. Intermídias, Serra, n. 5-6, p. 1-24, 2002.

MANNONI, Laurent. A grande arte da luz e da sombra: arqueologia do cinema. São Paulo: Editora Unesp, 2003.

MANOVICH, Lev. The language of new media. Cambridge, MA: MIT Press, 2001.

MICHAUD, Philippe-Alain. Aby Warburg e a imagem em movimento. Rio de Janeiro: Contraponto, 2013.

MOORE, Rachel. Hollis Frampton: (nostalgia). London: Afterall, 2006.

PIGNATARI, Décio. Semiótica e literatura. São Paulo: Cortez \& Moraes, 1979.

RANCIÈRE, Jacques. Le concept d'anachronisme et la vérité de l'historien. L'Inactual, Paris, n. 6, p. 53-68, 1996.

REVERDY, Pierre. L'image. Nord-Sud, Paris, v. 2, n. 13, p. 1-20, mar. 1918.

ROSA, Carlos Adriano Jeronimo de. O mutoscópio explica a invenção do pensamento de Santos Dumont: cinema experimental de reapropriação de arquivo em forma digital. 2008. 384 f. Tese (Doutorado em Ciências da Comunicação) - Universidade de São Paulo, São Paulo, 2008. 
SANTOS DUMONT, Alberto. O que eu vi o que nós veremos. São Paulo, 1918.

SILVEIRA, Celestino. Santos-Dumont, o homem que previu o drama. Revista da Semana, Rio de Janeiro, n. 11, p. 9-15, mar. 1945.

SKOLLER, Jeffrey. Shadows, specters, shards: making history in avant-garde film. Minneapolis: University of Minnesota Press, 2005.

STRAUVEN, Wanda. The cinema of attractions reloaded. Amsterdam: Amsterdam University Press, 2006.

TAUNAY, Affonso de. Guia da seção histórica do Museu Paulista. São Paulo: Imprensa Oficial do Estado, 1937.

UNIVERSIDADE DE SÃO PAUlO. Museu Paulista. Dossiê da Coleção Santos Dumont. São Paulo, 2000.

USAI, Paolo Cherchi. Silent cinema: an introduction. London: British Film Institute, 2003.

WHITE, Hayden. Figural Realism: studies in the mimesis effect. Baltimore: Johns Hopkins University Press, 2000.

WEES, William C. Recycled images: the art and politics of found footage films. New York: Anthology Fim Archives, 1993.

WYKEHAM, Peter. Santos Dumont: o retrato de uma obsessão. Rio de Janeiro: Civilização Brasileira, 1966.

XAVIER, Ismail. O discurso cinematográfico: a opacidade e a transparência. Rio de Janeiro: Paz e Terra, 2005.

. Alegorias do subdesenvolvimento. São Paulo: Cosac Naify, 2012.

YERUSHALMI, Yosef Hayim. Freud's Moses: Judaism terminable and interminable. New Haven: Yale University Press, 1991. 


\section{FILMOGRAFIA}

SANTOS Dumont: pré-cineasta? Direção: Carlos Adriano. Produção: Carlos Adriano e Bernardo Vorobow. São Paulo: Babushka, 2007-2010. 1 hd (63 min), son., color., digital.

SANTOSCÓPIO = Dumontagem. Direção: Carlos Adriano. Produção: Carlos Adriano e Bernardo Vorobow. São Paulo: Babushka, 2007-2009. 1 bobina cinematográfica (14 min), son., color., $35 \mathrm{~mm}$.

Artigo apresentado em 24/02/17. Aprovado em 29/06/17. 